\title{
Shallow rainwater lenses in deltaic areas with saline seepage
}

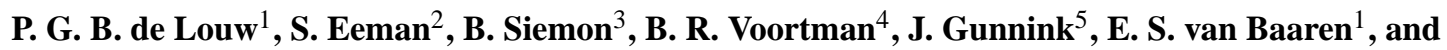 \\ G. H. P. Oude Essink ${ }^{1}$ \\ ${ }^{1}$ Deltares, Dept. of Soil and Groundwater, P.O. Box 85467, 3508 AL Utrecht, The Netherlands \\ ${ }^{2}$ Wageningen University, Environmental Sciences Group, Soil Physics, Ecohydrology and Groundwater Management, \\ P.O. Box 47, 6700 AA Wageningen, The Netherlands \\ ${ }^{3}$ Federal Institute for Geosciences and Natural Resources, Dept. of Groundwater and Soil Science, Stilleweg 2, \\ 30655 Hanover, Germany \\ ${ }^{4}$ KWR Watercycle Research Institute, P.O. Box 1072, 3430 BB, Nieuwegein, The Netherlands \\ ${ }^{5}$ TNO Geological Survey of the Netherlands, P.O. Box 80015, 3508 TA Utrecht, The Netherlands
}

Received: 15 July 2011 - Published in Hydrol. Earth Syst. Sci. Discuss.: 10 August 2011

Revised: 22 November 2011 - Accepted: 23 November 2011 - Published: 7 December 2011

\begin{abstract}
In deltaic areas with saline seepage, freshwater availability is often limited to shallow rainwater lenses lying on top of saline groundwater. Here we describe the characteristics and spatial variability of such lenses in areas with saline seepage and the mechanisms that control their occurrence and size. Our findings are based on different types of field measurements and detailed numerical groundwater models applied in the south-western delta of the Netherlands. By combining the applied techniques we could extrapolate measurements at point scale (groundwater sampling, temperature and electrical soil conductivity (TEC)-probe measurements, electrical cone penetration tests (ECPT)) to field scale (continuous vertical electrical soundings (CVES), electromagnetic survey with EM31), and even to regional scale using helicopter-borne electromagnetic measurements (HEM). The measurements show a gradual mixing zone between infiltrating fresh rainwater and upward flowing saline groundwater. The mixing zone is best characterized by the depth of the centre of the mixing zone $D_{\text {mix }}$, where the salinity is half that of seepage water, and the bottom of the mixing zone $B_{\text {mix }}$, with a salinity equal to that of the seepage water (Cl-conc. 10 to $\left.16 \mathrm{~g} \mathrm{l}^{-1}\right)$. $D_{\text {mix }}$ is found at very shallow depth in the confining top layer, on average at $1.7 \mathrm{~m}$ below ground level (b.g.l.), while $B_{\text {mix }}$ lies about $2.5 \mathrm{mb}$ b.g.l. The model results show that the constantly alternating upward and downward flow at low velocities in the confining layer is the main mechanism of mixing between rainwater and saline seepage and determines the position and extent of the mixing zone ( $D_{\text {mix }}$ and $\left.B_{\text {mix }}\right)$. Recharge, seepage flux, and drainage depth are the controlling factors.
\end{abstract}

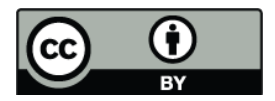

Correspondence to: P. G. B. de Louw (perry.delouw@deltares.nl)

\section{Introduction}

In many deltaic areas, the groundwater is saline because of seawater intrusion and marine transgressions (Custodio and Bruggeman, 1987; Stuyfzand and Stuurman, 1994; Weert et al., 2009; Post and Abarca, 2010). In areas that lie below mean sea level (m.s.l.) saline groundwater may reach the surface by upward groundwater flow, which we define here as seepage. This leads to salinization of surface waters and shallow fresh ${ }^{1}$ groundwater bodies and makes the water unfit for irrigation, drinking water supply or industrial purposes (e.g. van Rees Veilinga et al., 1981; van den Eertwegh et al., 2006; Giambastiani et al., 2007; de Louw et al., 2010, 2011). A future rise in sea level is expected to increase the seepage and salt loads to surface waters and reduce the availability of both fresh surface water and groundwater (e.g. Meisler et al., 1984; Navoy, 1991; Oude Essink, 1996; van der Meij and Minnema, 1999; Vandenbohede et al., 2008). Model simulations show that salt loads from groundwater seepage in several low-lying parts of the coastal zone of the Netherlands will be doubled due to sea level rise by $2100 \mathrm{AD}$ (Oude Essink et al., 2010).

In contrast to the salt loading process to surface waters by saline groundwater seepage, little attention has so far been given to the interaction of upward flowing saline groundwater with infiltrating rainwater in the topsoil, as illustrated in Fig. 1. The upward movement of saline groundwater prevents rainwater from infiltrating to greater depths, resulting

\footnotetext{
${ }^{1}$ In this paper, we classify groundwater salinity based on chloride $\left(\mathrm{Cl}^{-}\right)$concentration into fresh $\left(\mathrm{Cl}^{-}<0.3 \mathrm{gl}^{-1}\right)$, brackish $\left(>0.3 \mathrm{gl}^{-1} \mathrm{Cl}^{-}<1.0 \mathrm{gl}^{-1}\right)$ and salt $\left(\mathrm{Cl}^{-}>1.0 \mathrm{gl}^{-1}\right) . \mathrm{Cl}^{-}$is the major conservative anion in the coastal plain and subsurface of the Netherlands.
} 


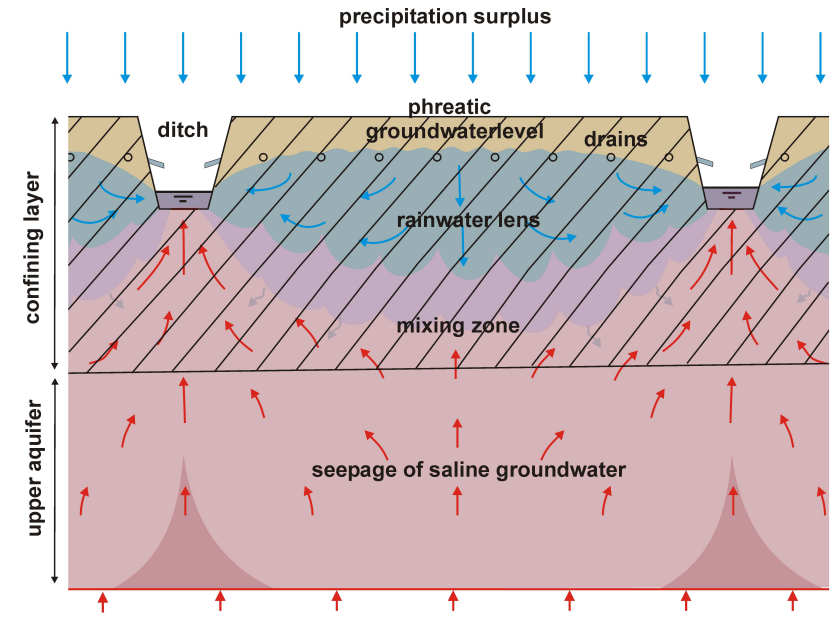

Fig. 1. Conceptual visualisation of a shallow rainwater lens on top of saline groundwater seepage.

in shallow rainwater lenses (Fig. 1). Under certain conditions the rainwater lens may become so small, or even disappear, that saline groundwater may reach the root zone via capillary rise, affecting crop growth (Steppuhn et al., 2005; Katerji et al., 2003; Flowers, 2004; Rozema and Flowers, 2008) and natural vegetation (Jolly et al., 2008; Antonellini and Mollema, 2009). Shallow rainwater lenses in areas with saline seepage are very vulnerable to climate change (changing precipitation surpluses) and to a rising sea level (enhancing seepage) as shown by Maas (2007).

Here we focus on the occurrence of shallow rainwater lenses in areas with saline seepage and the processes involved. So far, research into fresh rainwater lenses in saline groundwater has mainly been focused on so-called Badon Ghijben-Herzberg (BGH) freshwater lenses in elevated areas like sandy dunes along the coast and on small islands that lack an upward groundwater flow (e.g. Badon Ghijben, 1888; Herzberg, 1901; Fetter, 1972; van Dam and Sikkema, 1982; Meinardi, 1983; Underwood et al., 1992; Collins and Easley, 1999; Bakker, 2000). BGH-lenses are generally thick and the depth of the freshwater-saline interface $(H)$ is mainly controlled by the relative density difference $(\alpha)$ and the phreatic groundwater level $(h): H=h / \alpha$.

Some analytical and numerical steady-state approaches to modelling rainwater lenses under conditions of upward groundwater seepage have been described (Schot et al., 2004; Maas, 2007; Eeman et al., 2011). Eeman et al. (2011) investigated the parameter groups that dominate the mixing processes for physically feasible ranges of parameters, using the analytical approach by Maas (2007) and the numerical transport code SUTRA (Voss and Provost, 2008). Schot et al. (2004) used a numerical model to simulate the development of rainwater lenses in fens under fresh groundwater seepage conditions. So far, theoretical models for shallow fresh rainwater lenses have not been based on actual obser- vations, since there were no detailed measurements available. In addition, predicting the effects of climate change and sea level rise, and formulating mitigation measures is only meaningful when the current situation of these shallow rainwater lenses on top of seeping saline groundwater is known.

In this article we aim to determine the characteristics and spatial variability of rainwater lenses in areas with saline seepage based on field measurements and numerical density dependent groundwater models. Moreover, we determine the main factors that control the characteristics and occurrence of these shallow rainwater lenses. Our study area was the province of Zeeland, situated in the south-western delta of the Netherlands, where saline groundwater with chloride concentrations exceeding $10 \mathrm{gl}^{-1}$ is found within five meters below ground level (Goes et al., 2009). Different field techniques, namely groundwater sampling, TEC (temperature and electrical soil conductivity)-probe measurements, electrical cone penetration tests (ECPT), continuous vertical electrical soundings (CVES), electromagnetic survey with EM31 and helicopter-borne electromagnetic measurements (HEM) were used to map the thickness of these shallow rainwater lenses and the mixing zone from fresh to saline groundwater.

\section{Paleogeography, geomorphology and hydrogeology of study area}

The study area lies in the south-western delta of the Netherlands (Fig. 2a). The current landscape, groundwater flow systems and groundwater salinity mainly result from sequential Holocene marine transgressions and regressions, and human activities such as peat mining and land reclamation. Under a continuous sea level rise during the Holocene, Zeeland was submerged from $7500 \mathrm{BP}$ (before present) until $5000 \mathrm{BP}$ (van de Plassche, 1982; Vos and Zeiler, 2008) and the infiltration of seawater salinized the underlying Pleistocene aquifers by free convection (Post, 2004). After this period of maximum transgression, sedimentation processes began to dominate and, as a consequence, the land rose above mean sea level. Then peat was formed under freshwater conditions and this covered Zeeland between $3800 \mathrm{BP}$ and $2000 \mathrm{BP}$. Since Roman times, peat mining and drainage of the land by man has caused subsidence enhanced by marine erosion (Fig. 2b). Zeeland was again totally submerged from $350 \mathrm{AD}$ until $750 \mathrm{AD}$ (Fig. 2b). Around $1000 \mathrm{AD}$ people started to reclaim large pieces of land by the embankment of the salt marshes (supra-tidal flats) (Fig. 2b; Vos and Zeiler, 2008). Such an embanked land which is drained artificially is called a "polder" (van de Ven, 2003). Shrinkage of peat and clay by drainage and peat mining led to further subsidence of these polders, whereas the unembanked land was rising from sedimentation during high tides and storms (Vos and Zeiler, 2008). 


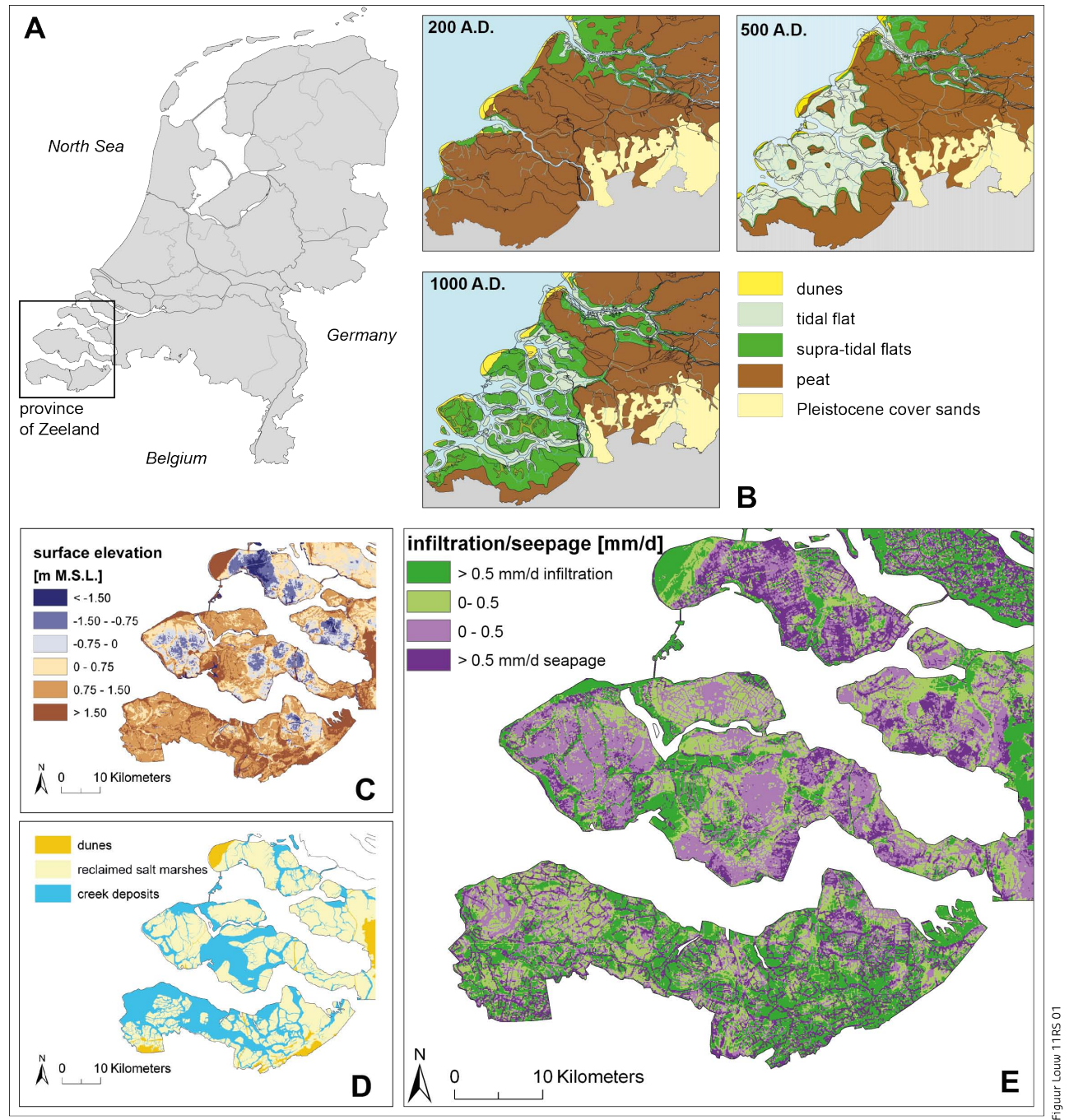

Fig. 2. (a) Location of study area. (b) Paleogeography of study area in 200 AD, 500 AD, 1000 AD (Vos and Zeiler, 2008; by courtesy of Vos). (c) Surface elevation. (d) Position of the dunes, reclaimed salt marshes and sandy creek deposits (from: REGIS II, 2005). (e) Infiltration and seepage flux (result of regional groundwater model; van Baaren et al., 2011).

The present topography is therefore a result of the age of reclamation; the older the land, the lower the surface elevation. The lowest polders are situated at -1.5 to $-2.5 \mathrm{~m} \mathrm{~m}$.s.l. whereas the more recent polders have their land surface above mean sea level (Fig. 2c). As the former tidal creeks consisted of sand, they did not subside like the surrounding clayey and peaty salt marshes. The present land surface at these sandy creek ridges is therefore often 0.5 to $1.5 \mathrm{~m}$ higher than the surrounding land (Fig. 2c-d). In the western coastal area, sandy dunes were formed during the Holocene that now reach elevations of $+30 \mathrm{~m}$ m.s.l. Taking into account that the present elevation has a large impact on the groundwater flow system, the study area can be divided into three major geomorphic units: (a) reclaimed salt marshes, (b) sandy creek ridges and (c) the dunes (Fig. 2d). Fresh rainwater infiltrates the dunes and the elevated sandy creek ridges, whereas up- ward groundwater seepage occurs mainly in the low-lying reclaimed salt marshes (Fig. 2e). The salt marshes are intensively drained by a regular system of ditches and tile drainage to make the land fit for agriculture. Tile drainage usually leads to the rapid discharge of shallow groundwater during rainfall events (e.g. Tiemeijer et al., 2007; van der Velde et al., 2009). The ditches lie some 50 to $300 \mathrm{~m}$ apart and tile drainage is applied at a depth of about $1 \mathrm{~m}$, with a distance of 10 to $15 \mathrm{~m}$ between the drains. Surface water levels are maintained at a nearly constant level by pumping and admission of water from surface water reservoirs at higher elevations, like in most lowland polder catchments, (e.g. de Louw et al., 2010).

Besides elevation and drainage characteristics, the composition of the Holocene deposits plays an important role in groundwater flow and the formation of shallow fresh 
rainwater lenses on top of the present saline groundwater. Due to the dynamic paleographical evolution of the study area during the Holocene, the lithology is fairly heterogeneous. An NW-SE lithological cross-section of the island of Schouwen-Duivenland shows the general build-up of the Holocene sediments on top of late Pleistocene cover-sands (Fig. 3). In most of the area, the fining upward sequence of the Holocene deposits resulted in a thin confining layer of clay and peat on top of an aquifer of Pleistocene and Holocene fine to coarse sands (upper aquifer). The confining top layer of clay and peat is on average $4 \mathrm{~m}$ thick. The upper aquifer of Holocene and Pleistocene sands has a thickness of 20 to $60 \mathrm{~m}$ and is separated from the lower aquifer by a $5 \mathrm{~m}$ thick clay layer that is sometimes absent. The geohydrological base varies from a depth of $130 \mathrm{~m}$ in the northern part to $30 \mathrm{~m}$ in the southern part of the study area. For the development of rainwater lenses in saline groundwater, the shallow part of the geohydrology of the study area, i.e. the upper aquifer and confining top layer, is of main interest. We define seepage as the upward groundwater flow from the upper aquifer into the confining top layer (Fig. 1). This seepage water, groundwater coming from the upper aquifer, will eventually exit the groundwater system by either drainage or evapotranspiration.

\section{Materials and methods}

\subsection{Mapping rainwater lenses}

We used different geophysical and hydrological techniques to map the characteristics of rainwater lenses on top of upward-seeping saline groundwater. We carried out the measurements at different spatial scales, varying from point scale to island scale. As salinity changes rapidly in space and with depth, we needed high-resolution techniques that could record this variability. We applied the following techniques to obtain detailed salinity-depth profiles at point scale: electrical soil conductivity measurements using the TEC-probe, groundwater sampling at small depth intervals, and electrical cone penetration tests (ECPT). We used non-invasive continuous vertical electrical soundings (CVES) and surface electromagnetic measurements (EM31) to map the spatial variation of rainwater lenses within an agricultural field $\left(0.05 \mathrm{~km}^{2}\right)$. A helicopter-borne frequency-domain electromagnetic (HEM) survey was performed to map the thickness of rainwater lenses for a large area on the island of Schouwen-Duivenland $\left(56 \mathrm{~km}^{2}\right)$. Figure $4 \mathrm{a}-\mathrm{d}$ shows the locations of the different measurements in the study area. At site 11, an agricultural field (Fig. 4c), we applied all our measurement techniques to compare their results and to improve the inversion models of the geophysical techniques. This site was chosen because of its position at a transition from a low-lying, clayey reclaimed salt marsh at $-0.7 \mathrm{~mm}$.s.l. to a higher sandy creek ridge lying at $-0.2 \mathrm{~m} \mathrm{~m}$.s.l. (Fig. $4 \mathrm{c}$ ). The measurement techniques will be described briefly below.

\subsubsection{TEC-probe}

The TEC-probe is suitable for manual 1-D measurements of temperature and the electrical conductivity $\left(\mathrm{EC}_{\text {soil }}\right)$ of soft soils like peat and clayey soils (van Wirdum, 1991). The electrodes and temperature sensor are located at the far end of the probe. The probe has a diameter of $22 \mathrm{~mm}$ and the electrode distance is $50 \mathrm{~mm}$. We carried out TEC-probe measurements once at 27 agricultural sites with differing geohydrology and geomorphology (Fig. 4a). At each site, TECprobe measurements were done in a ditch and at different distances from the ditch; from the groundwater level downward at $0.1 \mathrm{~m}$ intervals until a depth of $4.0 \mathrm{~m}$. Measured $\mathrm{EC}_{\text {soil }} \mathrm{s}$ were automatically corrected to obtain a specific $\mathrm{EC}_{\text {soil }}$ for a reference temperature of $25^{\circ} \mathrm{C}$. To obtain the electrical conductivity of groundwater $\left(\mathrm{EC}_{\mathrm{w}}\right), \mathrm{EC}_{\text {soil }}$ must be multiplied by the formation factor (FF), which depends mainly on the lithology (Archie, 1942; Keary and Brooks, 1991; Friedman, 2005). We determined the formation factor (FF) for seven different soil types based on 584 measured $\mathrm{EC}_{\mathrm{w}}-\mathrm{EC}_{\text {soil }}$ pairs (Table 1). $E_{\text {soil }}$ was measured with the TEC-probe and $\mathrm{EC}_{\mathrm{w}}$ was obtained by groundwater sampling. $\mathrm{EC}_{\mathrm{w}}$-values were transformed to chloride concentrations using a calibration curve based on a linear regression analysis $\left(R^{2}=0.98\right)$ of 79 groundwater samples:

$\mathrm{Cl}\left(\mathrm{g} \mathrm{l}^{-1}\right)=\mathrm{EC}_{\mathrm{w}}\left(\mathrm{mS} \mathrm{cm}^{-1}\right) \cdot 0.36-0.45$.

The 79 groundwater samples were taken from 79 different piezometers at site 11 and site 26 (see Sect. 3.1.2). Simultaneously with the TEC-probe measurement, we made a detailed soil description to assess the formation factor. The TEC-probe measurements were carried out in the period January-March 2007.

\subsubsection{Groundwater sampling}

From the 27 TEC-probe sites we selected two sites on the island of Schouwen-Duivenland, site 11 (Fig. 4c) and site 26 (Fig. 4d), where we installed clusters of piezometers for sampling groundwater to derive chloride-depth profiles. The clusters were installed in ditches and at different distances from the ditches in the fields (Fig. 4c-d). The clusters in the fields were located between two drains, except for the two clusters $\mathrm{mp} 5$ and $\mathrm{mp} 6(\mathrm{mp}=$ monitoring point $)$ at site 26 . These two clusters were positioned near $(<0.2 \mathrm{~m})$ a drain to measure the effect of tile drainage. Each cluster contained 6 to 7 piezometers with $0.16 \mathrm{~m}$ long screens at depths (bottom of screen) of $0.8 \mathrm{~m}, 1.0 \mathrm{~m}, 1.3 \mathrm{~m}, 1.6 \mathrm{~m}, 2.0 \mathrm{~m}, 3.0 \mathrm{~m}$ and $4.0 \mathrm{~m}$ b.g.l. Before taking groundwater samples, we extracted all the water from the piezometers and waited several hours until the piezometers had re-filled with groundwater. The electrical conductivity of the sampled groundwater 


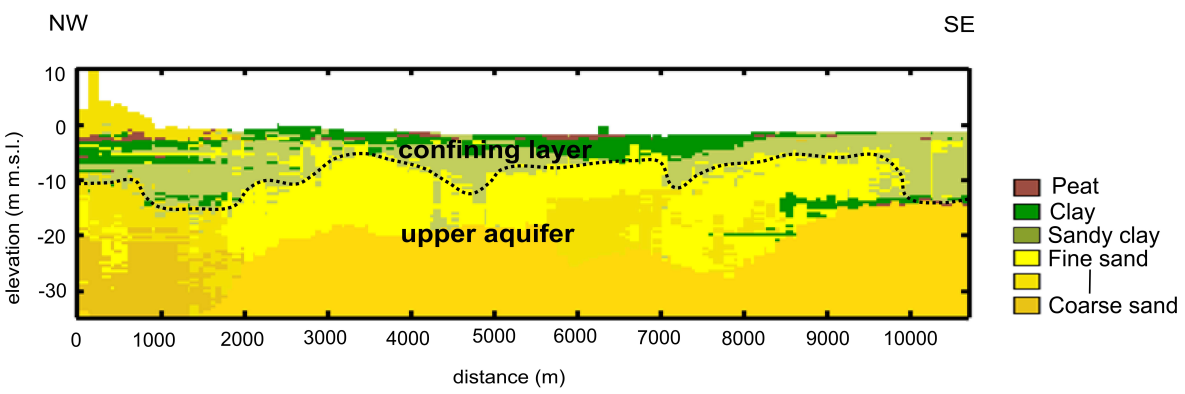

Fig. 3. A NW-SE lithological cross-section of the island of Schouwen-Duivenland (see Fig. 4 for location of cross-section). The cross-section is derived from a detailed 3-D geological model of Zeeland based on 5 drillings per $1 \mathrm{~km}^{2}$ that were classified into geological units (GeoTOP, Stafleu et al., 2011).
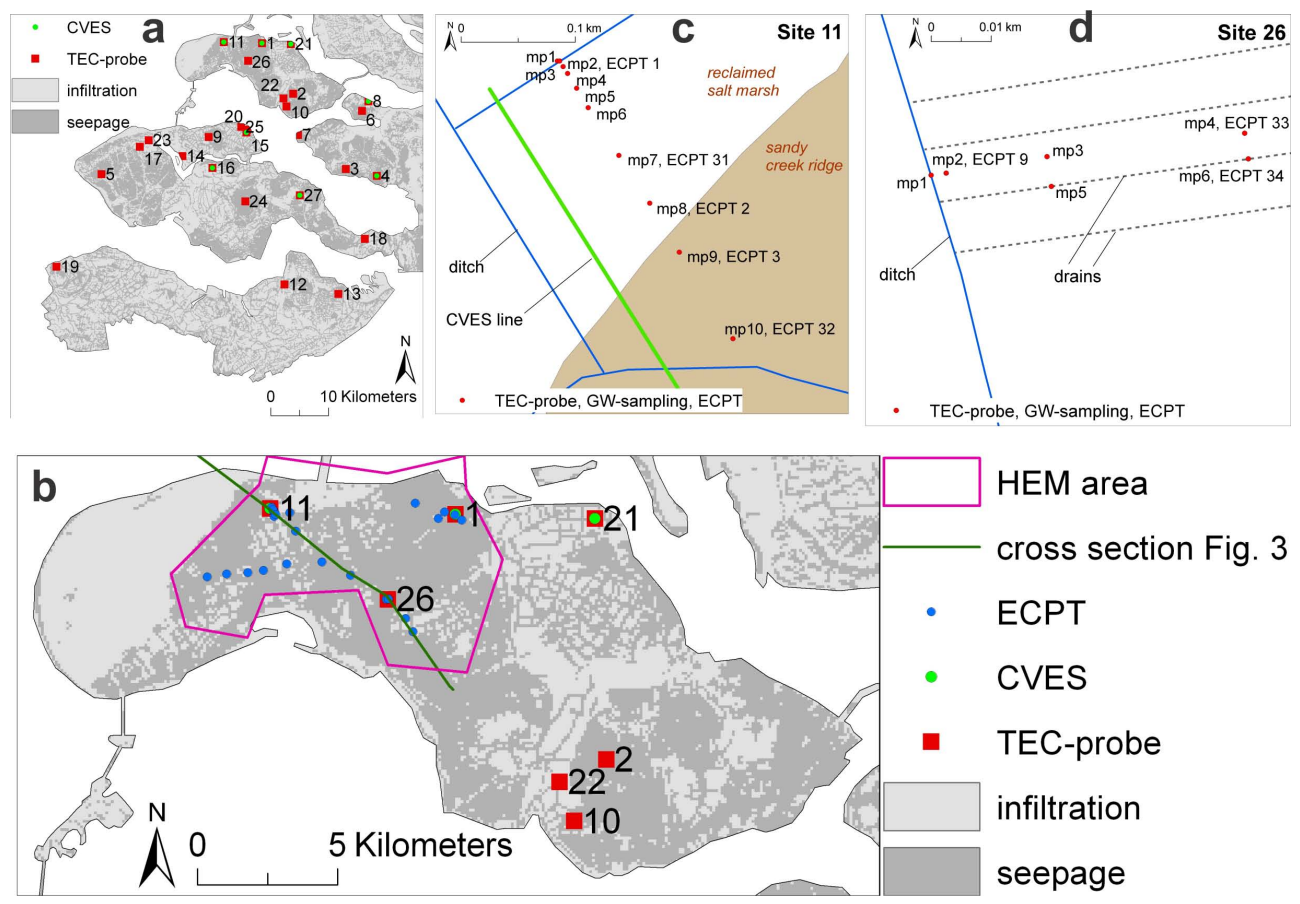

HEM area

cross section Fig. 3

ECPT

CVES

TEC-probe

infiltration

seepage

Fig. 4. Position of field measurements at different scales. (a) Province of Zeeland. (b) Island of Schouwen-Duivenland. (c) Agricultural field, site 11. (d) Agricultural field, site 26.

was measured in the field monthly for a period of $2 \mathrm{yr}$ (January 2009-December 2010) and chloride was analyzed in the laboratory in April 2009. Hydraulic heads were measured as well to determine the head change with depth. The heads were monitored hourly in the period September 2008 until January 2011 using CTD-diver data loggers. Heads were corrected for density differences by conversion to freshwater heads (Post et al., 2007).

\subsubsection{Continuous vertical electrical soundings: CVES}

We carried out the CVES-measurements in profiles (with a length of 150 to $350 \mathrm{~m}$ ) perpendicular to the ditches at 8 of the 27 TEC-probe sites (Fig. 4a). Some of the results and a detailed set up of the CVES-measurements were described by Goes et al. (2009). The CVES measurements were done with an AbemSAS4000 connected to four multielectrode cables, with electrode spacing of $1 \mathrm{~m}$ to obtain a detailed resolution both horizontally and in depth. The measured electrical resistivity data were inverted into real soil resistivities using SensInv2D (Geotomographie, 2004). The CVES-measurements were carried in the period SeptemberOctober 2007.

\subsubsection{Electromagnetic EM31 survey}

We carried out an EM31-survey at site 11 in September 2009 to obtain an overview of the spatial variation of groundwater 
Table 1. Formation factors (FF) for different lithological units.

\begin{tabular}{lrrr}
\hline Lithology & Average FF & Std & $\begin{array}{r}\text { No. } \\
\text { of samples }\end{array}$ \\
\hline Peat & 2.1 & 0.7 & 41 \\
Clay & 2.5 & 0.6 & 192 \\
Sandy clay/clayey sand & 2.8 & 0.8 & 52 \\
(Clayey) fine sand & 3.2 & 0.4 & 299 \\
Medium coarse sand & $4^{*}$ & & \\
Coarse sand & $5^{*}$ & & \\
Sand with gravel & $6-7^{*}$ & & \\
\hline
\end{tabular}

* FF taken from Goes et al. (2009).

salinity in the shallow subsoil within one agricultural field. The EM31 is an electromagnetic instrument that measures the apparent electrical bulk conductivity of the shallow subsoil (McNeill, 1980). The upper layers contribute more to the bulk conductivity than the lower layers. The average penetration depth of these measurements was about $6 \mathrm{~m}$, which is less than the penetration depth of the CVES-measurements (about $20 \mathrm{~m}$ ). However, the EM31-measurements allowed us to map a larger area in a horizontal plane (about $0.1 \mathrm{~km}^{2}$ ). The EM31-measurements with a spacing of $5 \mathrm{~m}$ have been interpolated to a conductivity map, which represents the bulk conductivity of the top $6 \mathrm{~m}$ of the subsoil.

\subsubsection{Helicopter-borne electromagnetic measurements (HEM)}

A helicopter-borne survey was conducted by the airborne geophysics group of the German Federal Institute for Geosciences and Natural Resources (BGR) on 25-26 August 2009 (Siemon et al., 2011). The survey, covering a large part of the island of Schouwen-Duivenland (Fig. 4b) required three survey flights to map an area of about $56 \mathrm{~km}^{2}$ with $31 \mathrm{WNW}$-ESE lines and $16 \mathrm{NNE}-\mathrm{SSW}$ tie lines at $200 \mathrm{~m}$ and $500 \mathrm{~m}$ line spacing, respectively, totalling 313 line-km. Electromagnetic, magnetic and radiometric data, as well as position data, were acquired simultaneously. The electromagnetic system we used was a RESOLVE towed "bird" consisting of five horizontal-coplanar (HCP) coil systems and one vertical-coaxial (VCX) coil system, with measuring frequencies ranging from $387 \mathrm{~Hz}$ to $133 \mathrm{kHz}$. The average sensor altitude was $33 \mathrm{~m}$ above ground level. About 84300 resistivity-depth inversion models were derived from the HCP data using a Marquardt-Levenberg smooth multilayer inversion procedure (Siemon et al., 2009). The models consist of 15 layers. All resistivities and the thickness of the top layer are derived by the inversion procedure. The thickness of the other 14 layers remained fixed during the inversion and increased slightly with depth. The degree of model smoothing was optimised in order to avoid oscillation of the model resistivities.

\subsubsection{Electrical cone penetration tests (ECPT)}

We contracted a geotechnical company (www.bmned.com) to carry out 23 ECPTs on Schouwen-Duivenland to obtain 1-D electrical conductivity profiles down to a depth of $25 \mathrm{~m}$ (Fig. 4b). The technique is comparable with a manual TECprobe measurement but can also be applied in sandy soils and down to greater depths. Besides measurements of the soil's electrical conductivity $\left(\mathrm{EC}_{\text {soil }}\right)$ during penetration, the cone sleeve and tip friction were also measured to determine the lithological composition (BMNED, 2011). The ECPTs were carried out in the HEM pilot area (Fig. 4b) in March 2011, in order to derive conductivity depth profiles, which could be subsequently used to check the calibration of the HEM system and to optimize the inversion of the HEM data.

\subsection{Numerical modelling of rainwater lenses}

We constructed two different types of groundwater models to increase our insight into rainwater lenses on top of saline groundwater: (1) a 3-D-model that was able to reproduce the different types of field measurements at site 11, and (2) various smaller-scale 2-D conceptual models to focus on the mixing of saline seepage and infiltrating rainwater, and the flow to drains in detail. These models were used to analyse the sensitivity of different parameters.

\subsubsection{Set-up of 3-D-model}

We set up the 3-D-model with the numerical transport code MOCDENS3D (Oude Essink, 2001a) for site 11 and a small area around it (modelled area is $1 \mathrm{~km}^{2}$ ) at a transition from a low-lying, clayey reclaimed salt marsh to a higher sandy creek ridge (Fig. 4b-c). Different kinds of measurements were available for this site to evaluate the performance of the model. The model area was divided into cells of 5 by $5 \mathrm{~m}$ and the subsoil was divided into 41 layers of 0.3 to $5 \mathrm{~m}$, up to a maximum depth of $35 \mathrm{~m}$, to accurately model salt transport. The geohydrological schematization and parameterization was based on our field measurements and the Dutch Geohydrological Information System (REGIS II, 2005). The molecular diffusion coefficient $D_{\mathrm{m}}$ for porous media was assumed to be $8.6 \times 10^{-5} \mathrm{~m}^{2} \mathrm{~d}^{-1}$. The longitudinal dispersivity was set equal to $0.1 \mathrm{~m}$ and the ratio transversal to longitudinal dispersivity was 0.1 . These rather small values are based on numerous case studies of Dutch and Belgian aquifer systems with marine and fluvial deposits (e.g. Stuyfzand, 1993; Lebbe, 1999; van Meir, 2001; Oude Essink, 2001b; Vandenbohede and Lebbe, 2007). Fixed heads were applied at the model boundaries and were deduced from the regional groundwater model of the province of Zeeland (van Baaren et al., 2011). We determined the location and dimensions of ditches and subsurface drains in the field and applied it to the model. The period of 1906-2006 was simulated with stress periods of 10 days. Recharge was calculated from 
precipitation and evapotranspiration data from two nearby meteorological stations (Kerkwerve and Wilhelminadorp) of the Royal Netherlands Meteorological Institute (KNMI). A 100-yr simulation period was long enough for the groundwater chloride distribution at the sandy creek ridges to reach a state of equilibrium with the boundary conditions.

\subsubsection{Set-up of 2-D-model}

From the 3-D-model we zoomed into low-lying seepage areas to focus on the mixing of infiltrating fresh rainwater and upward-seeping saline groundwater between two ditches. Based on our findings with the 3-D-model and our field measurements, we constructed a conceptual cross-sectional 2D-model between two ditches of a tile-drained agricultural field with upward-seeping saline groundwater (Fig. 5). For this modelling exercise we used the numerical transport code Seawat (Langevin et al., 2003). The cell size in a horizontal direction was 1 by $1 \mathrm{~m}$ and the layer thickness in the vertical direction was $0.1 \mathrm{~m}$. The total thickness of the reference model was $3.0 \mathrm{~m}$, which equals the thickness of the confining layer. Parameter values for the reference model and sensitivity models are given in Table 2 and are based on field data. We assumed that all the incoming fluxes due to recharge and seepage between the ditches discharge into drains and ditches and therefore applied no-flow boundaries at the model sides. We applied a constant upward seepage flux $Q_{\mathrm{s}}$ with chloride concentration $\mathrm{Cl}_{\mathrm{S}}$ from the upper aquifer into the Holocene confining layer (Fig. 5). Although the confining layer consists of a sequence of different soil types, we considered it to be homogeneous. The effect of soil composition heterogeneity is addressed in the sensitivity analysis by applying a $0.2 \mathrm{~m}$ thick layer with a very low permeability at different depths in the confining layer, as we think this may influence groundwater flow and solute transport in the shallow groundwater system.

The initial groundwater chloride concentration in all model layers was set equal to the chloride concentration of the upward-seeping groundwater $\mathrm{Cl}_{\mathrm{s}}$. A rainwater lens can develop in this saline groundwater body under a variable recharge with fresh rainwater $\left(\mathrm{Cl}=0.02 \mathrm{~g}^{-1}\right)$ and a constant seepage flux. Daily values of recharge were determined from daily precipitation $P$ and potential reference crop evapotranspiration ET at the KNMI meteorological stations. We used data from the year 2005 because these were representative for the annual average precipitation surplus $\left(=0.75 \mathrm{~mm} \mathrm{~d}^{-1}\right)$, and applied them for every year during the whole simulation period. The total precipitation and evapotransipration for the winter months (October until March) was $397 \mathrm{~mm}$ and $108 \mathrm{~mm}$ respectively. The total precipitation and evapotranspiration for the summer months (April until September) was $425 \mathrm{~mm}$ and $440 \mathrm{~mm}$ respectively. A simulation period of $30 \mathrm{yr}$ was long enough for all model simulations to reach a stationary situation, which means that the annual

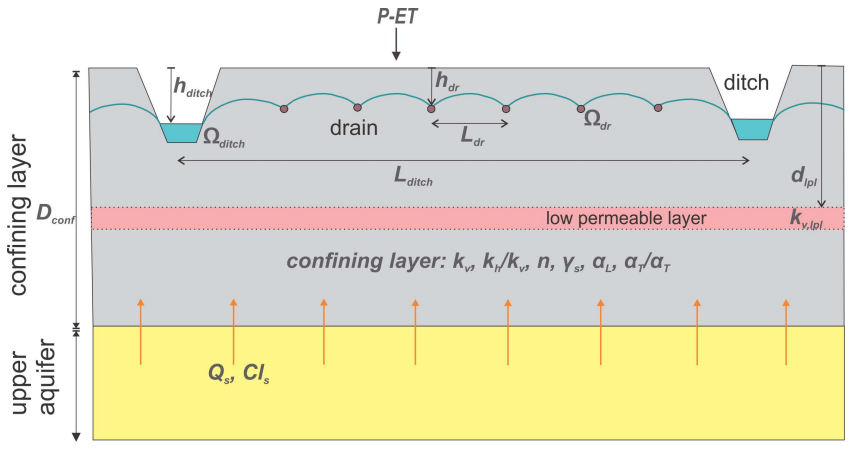

Fig. 5. Conceptual schematization of the cross-sectional 2-Dmodels.

mass balance did not change significantly from year to year. The model output was analysed for the thirtieth year.

\subsubsection{Sensitivity analysis}

We carried out a sensitivity analysis with the 2-D-model for 19 model parameters, which are mainly physical and geographical parameters (Table 2). One parameter at a time was modified while the others remained fixed. The modified parameter values were based on field measurements and surveys, and geographical and geological data; they represent plausible ranges for the study area. We tested the parameter sensitivity for rainwater lens characteristics for a location in the middle between two drains (bdr) and for a location at a drain (dr), both at the largest possible distance from the ditches (Fig. 5). Besides the sensitivity analysis, we used results from the 2-D-models to study vertical flow processes in more detail at and between the drains with respect to lens characteristics.

\section{Results and discussion}

\subsection{Characteristics of the mixing zone in seepage areas}

The form of the mixing zone between infiltrating rainwater and saline groundwater was obtained accurately with the point measurements by the TEC-probe (Fig. 6) and ECPT soundings (Fig. 7). At 17 of the 27 TEC-probe sites, we measured a gradual mixing zone between rainwater and saline groundwater; these are shown in Fig. 6. At the other 10 locations, we found a constant and fresh groundwater profile with depth. The measured smooth curved mixing zones are well described by the spatial moment method (Eeman et al., 2011). With this method the chloride concentration change with depth, i.e. the derivative of the chloride profile, is described by a normal distribution function, from which the centre of mass (1st moment) indicates the centre of the mixing zone $D_{\text {mix }}$ (first graph in Fig. 6). The variance (2nd moment) is a measure of the extent of the mixing zone. By 
Table 2. Parameter values of the 2-D reference model (Ref) and the sensitivity models (Ref--, Ref-, Ref + , Ref ++ ).

\begin{tabular}{|c|c|c|c|c|c|c|c|c|}
\hline & Parameter & Description & Unit & $\operatorname{Ref}--$ & $\operatorname{Ref}-$ & Ref & $\operatorname{Ref}+$ & Ref ++ \\
\hline 1 & $Q_{\mathrm{s}}$ & seepage flux & $\mathrm{mm} \mathrm{d}^{-1}$ & 0.05 & 0.15 & 0.25 & 0.5 & 1.0 \\
\hline 2 & $P-E T$ & recharge (average) & $\mathrm{mm} \mathrm{d}^{-1}$ & 0.25 & 0.5 & 0.75 & 1.0 & 1.25 \\
\hline 3 & $\mathrm{Cl}_{\mathrm{s}}$ & Cl-conc seepage & $\mathrm{g}^{-1}$ & 0.01 & 5.0 & 10.0 & 15.0 & 19.0 \\
\hline 4 & $L_{\mathrm{dr}}$ & spacing between 2 subs. drains & $\mathrm{m}$ & 2.5 & 5 & 10 & 15 & 20 \\
\hline 5 & $h_{\mathrm{dr}}$ & depth of drains & $\mathrm{m}$ & -1.4 & -1.2 & -1 & -0.8 & -0.6 \\
\hline 6 & $\Omega_{\mathrm{dr}}$ & drainage resistance & $\mathrm{d}$ & 0.5 & 1 & 2.5 & 5 & 7.5 \\
\hline 7 & $L_{\text {ditch }}$ & spacing between 2 ditches & $\mathrm{m}$ & 25 & 50 & 100 & 150 & 200 \\
\hline 8 & $h_{\text {ditch }}$ & surface water level & $\mathrm{m}$ & -1.75 & -1.5 & -1.25 & -1 & -0.75 \\
\hline 9 & $\Omega_{\text {ditch }}$ & drainage resistance ditch & d & 1 & 2.5 & 5 & 10 & 20 \\
\hline 10 & $D_{\text {conf }}$ & thickness confining layer & $\mathrm{m}$ & 0 & 2 & 3 & 4.5 & 6 \\
\hline 11 & & vert. hydr. conductivity of confining layer & $\mathrm{md}^{-1}$ & $0.1 \times 10^{-2}$ & $0.5 \times 10^{-2}$ & $\mathbf{1 . 0} \times \mathbf{1 0}^{-2}$ & $2.5 \times 10^{-2}$ & $5.0 \times 10^{-2}$ \\
\hline 12 & $k_{\mathrm{h}} / k_{\mathrm{V}}$ & anisotropy factor $\left(k_{\mathrm{V}}=\right.$ constant $)$ & - & 1 & 2.5 & 5 & 7.5 & 10 \\
\hline 13 & $n$ & porosity & - & 0.06 & 0.1 & 0.14 & 0.18 & 0.22 \\
\hline 14 & $\gamma_{\mathrm{s}}$ & specific yield & - & 0.15 & 0.2 & 0.25 & 0.3 & 0.35 \\
\hline 15 & $d_{\mathrm{lpl}}$ & depth low permeable layer (LPL) & $\mathrm{m}$ & -0.7 & -1.0 & none & -1.5 & -2.5 \\
\hline 16 & $k_{\mathrm{v}-\mathrm{lpl}, 1.5}$ & $k_{\mathrm{V}}$ of LPL, depth LPL $=-1.5 \mathrm{~m}$ & $\mathrm{md}^{-1}$ & $0.3 \times 10^{-3}$ & $0.6 \times 10^{-3}$ & $1.2 \times 10^{-3}$ & $2.4 \times 10^{-3}$ & $4.8 \times 10^{-3}$ \\
\hline 17 & $k_{\mathrm{v}-\mathrm{pl}, 2.5}$ & $k_{\mathrm{V}}$ of LPL, depth LPL $=-2.5 \mathrm{~m}$ & $\mathrm{md}^{-1}$ & $0.3 \times 10^{-3}$ & $0.6 \times 10^{-3}$ & $1.2 \times 10^{-3}$ & $2.4 \times 10^{-3}$ & $4.8 \times 10^{-3}$ \\
\hline 18 & $\alpha_{\mathrm{L}}$ & longitudinal dispersivity coefficient & $\mathrm{m}$ & 0.01 & 0.05 & 0.1 & 0.25 & 0.5 \\
\hline 19 & $\alpha_{\mathrm{L}} / \alpha_{\mathrm{T}}$ & ratio. $\alpha_{\mathrm{T}}=$ transversal dispersivity coeff. & - & 1 & 5 & 10 & 15 & 20 \\
\hline
\end{tabular}
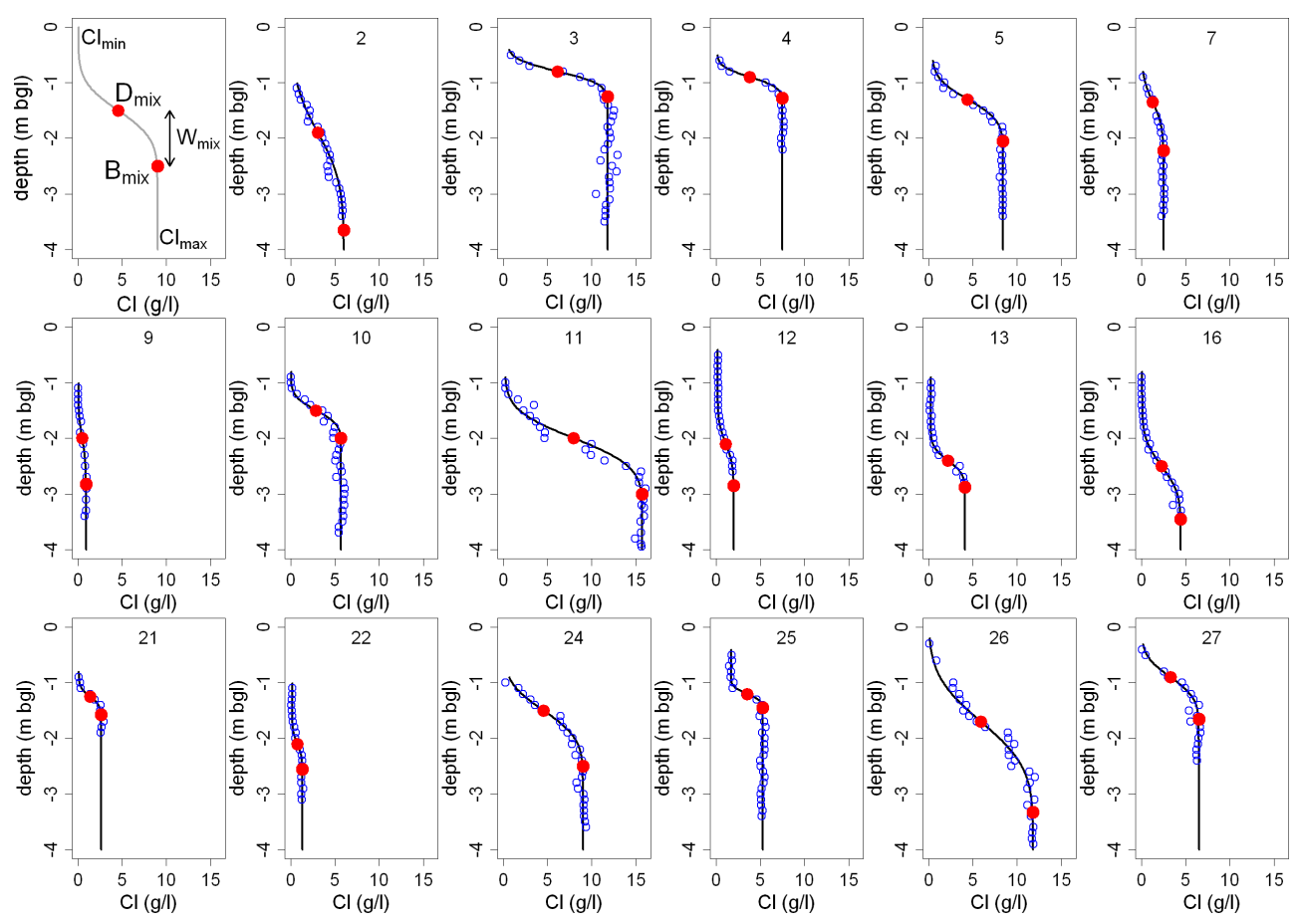

Fig. 6. Characteristics of a rainwater lens, $D_{\operatorname{mix}}, B_{\operatorname{mix}}, W_{\operatorname{mix}}, \mathrm{Cl}_{\min }, \mathrm{Cl}_{\max }$ (first plot) and 17 measured salinity profiles with the TEC-probe (blue circles) at different seepage locations in the province of Zeeland (see Fig. 4a for TEC-probe locations). The measured salinity profiles are characterized by the fitted salinity profiles based on spatial moments (black line). 


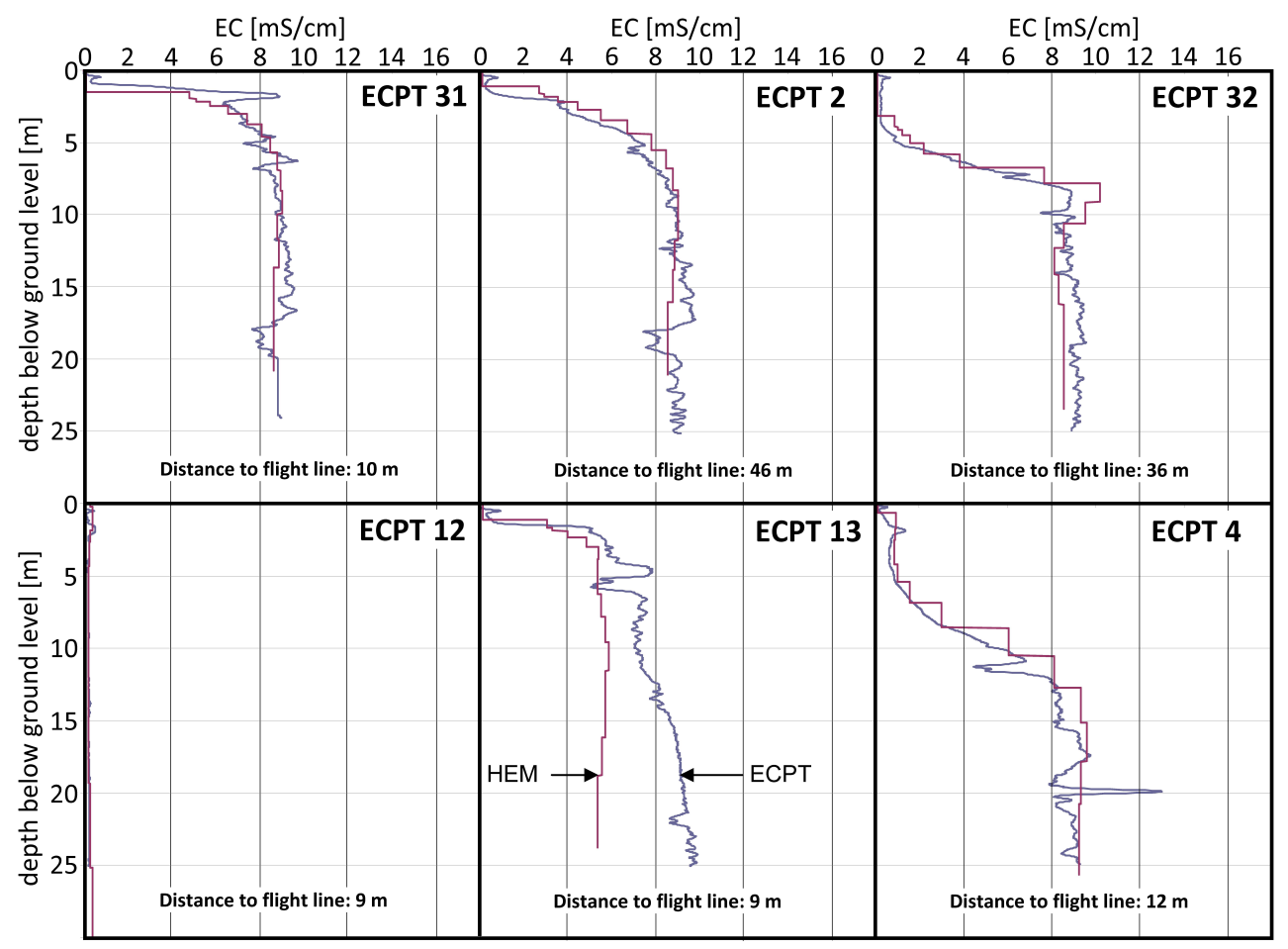

Fig. 7. Comparison of six ECPT soundings and smooth 15-layer HEM inversion models (for location see Fig. 14).

fitting the normal distribution function through the measurements, we derived five characteristics from it (first graph in Fig. 6): the depth of the centre of the mixing zone $D_{\text {mix }}$, the bottom of the mixing zone $B_{\text {mix }}$, the half-width of the mixing zone $W_{\text {mix }}\left(=D_{\text {mix }}-B_{\text {mix }}\right)$, and the minimum and maximum chloride concentrations $\mathrm{Cl}_{\min }$ and $\mathrm{Cl}_{\text {max }} . B_{\text {mix }}$ was defined as the depth where the chloride concentration was $\mathrm{Cl}_{\max }$. We used these lens characteristics in the further analysis of our measurements and model results.

The lens characteristics $D_{\text {mix }}, B_{\text {mix }}$ and $W_{\text {mix }}$ derived from the TEC-probe and ECPT measurements are summarized in Table 3. In the seepage areas, the depth of the centre of the mixing zone was found to be very shallow with a median depth of $D_{\text {mix }}$ of $1.7 \mathrm{~m}$ b.g.l. Mixing occurred no deeper than $5.5 \mathrm{~m}$ depth $\left(=B_{\mathrm{mix}}\right)$ and always in the confining layer. TECprobe results showed a large variation of $\mathrm{Cl}_{\max }, 0.9 \mathrm{~g} \mathrm{l}^{-1}$ to $15.7 \mathrm{gl}^{-1}$ (Fig. 6). The ECPT conductivity profiles, which go much deeper than TEC-probe profiles, showed that below the mixing zone the salinity remains relatively constant (at value $\mathrm{Cl}_{\max }$ ) until a depth of at least $25 \mathrm{~m}$ (Fig. 7). However, there was one exception: ECPT-12 was located in a seepage area at about $-1.5 \mathrm{~m}$ m.s.l. and showed a constant freshwater profile to a depth of $25 \mathrm{~m}$. The contrast with the salinity profile of ECPT-13 (with $D_{\text {mix }}$ at $1.5 \mathrm{~m}$ b.g.l, situated only $600 \mathrm{~m}$ from ECPT-12 and at the same elevation) is large. However, the explanation was rather simple: the freshwater profile at ECPT-12 was caused by lateral fresh groundwater flow from the elevated dunes (at $1 \mathrm{~km}$ to the west) that did not reach
ECPT-13 (see also HEM results in Sect. 4.3). The ECPTs are additionally valuable for the thicker rainwater lenses in the elevated areas, such as the sandy creek ridges (e.g. ECPT-32 and ECPT-4 in Fig. 7). Nine ECPTs were made at the sandy creek ridges where $D_{\text {mix }}$ varied between 4 and $11 \mathrm{~m}$ depth, and $B_{\text {mix }}$ varied between 8 and $14 \mathrm{~m}$ depth (Table 3 ).

The TEC-probe and ECPT data showed there was no sharp boundary between infiltrating fresh rainwater and saline seepage groundwater, but a gradual mixing zone with a median half-width $W_{\text {mix }}$ of $0.9 \mathrm{~m}$. Although this is much smaller than at the sandy creek ridges with a median $W_{\text {mix }}$ of $3.0 \mathrm{~m}$ (Table 3 ) and what is usually found for BGH-lenses on islands and dunes (e.g. Fetter, 1972; Underwood et al., 1992; Stuyfzand, 1993; Sakr, 1999), the mixing zone in the seepage areas can be labelled as relatively wide compared to its depth. Therefore, the analytical and numerical approaches that assume a sharp interface and satisfactorily simulate BGH-lenses (e.g. according to van der Veer, 1977; van Dam and Sikkema, 1982; Sikkema and van Dam, 1982; Sakr, 1999; Boekelman, 2001) should not be applied to these shallow rainwater lenses. As the mixing zones occur at shallow depth, their position and width is of great importance for the freshwater available for crop growth. In most seepage areas, we did not find any fresh groundwater (i.e. $\mathrm{Cl}^{-}<0.3 \mathrm{gl}^{-1}$ ). The upper groundwater is already a mix of seepage water and rainwater, which indicates that part of the mixing process very likely occurs in the unsaturated zone. 
Table 3. Summary of lens characteristics in seepage and infiltration areas derived from TEC-probe and ECPT measurements.

\begin{tabular}{|c|c|c|c|c|c|c|c|c|c|}
\hline & \multirow[b]{2}{*}{ Lens characteristic } & \multirow[b]{2}{*}{ Unit } & \multicolumn{3}{|c|}{ TEC-probe } & \multicolumn{3}{|c|}{ ECPT } & \multirow{2}{*}{$\begin{array}{l}\text { TEC + ECPT } \\
\text { Median }\end{array}$} \\
\hline & & & Range & Median & No. & Range & Median & No. & \\
\hline \multirow{3}{*}{$\begin{array}{l}\text { Seepage } \\
\text { areas }\end{array}$} & $D_{\operatorname{mix}}$ & m b.g.l. & $0.8-2.5$ & 1.5 & 17 & $1.2-3.5$ & 1.7 & 13 & 1.7 \\
\hline & $B_{\text {mix }}$ & m b.g.l. & $1.2-3.6$ & 2.5 & 17 & $2.0-5.5$ & 3.7 & 13 & 2.8 \\
\hline & $W_{\operatorname{mix}}$ & $\mathrm{m}$ & $0.2-1.7$ & 0.7 & 17 & $0.5-3.7$ & 1.5 & 13 & 0.9 \\
\hline \multirow{3}{*}{$\begin{array}{l}\text { Infiltration } \\
\text { areas }\end{array}$} & $D_{\operatorname{mix}}$ & m b.g.l. & $>4.0$ & $>4.0$ & 10 & $4.0-11.0$ & 6.3 & 9 & \\
\hline & $B_{\text {mix }}$ & m b.g.l. & $>4.0$ & $>4.0$ & 10 & $8.0-14.0$ & 8.5 & 9 & \\
\hline & $W_{\operatorname{mix}}$ & $\mathrm{m}$ & $?$ & $?$ & 10 & $1.0-5.5$ & 3.0 & 9 & \\
\hline
\end{tabular}

Maximum penetration depth of TEC-probe was $4 \mathrm{~m}$ b.g.l., penetration depth of ECPT was $25 \mathrm{~m}$ b.g.l.

$D_{\text {mix }}=$ centre of mixing zone, $B_{\text {mix }}=$ bottom of mixing zone.

$W_{\text {mix }}=$ half width of mixing zone $\left(=D_{\text {mix }}-B_{\text {mix }}\right)$.

\subsection{Rainwater lens variation within agricultural fields}

\subsubsection{Monitoring results at agricultural sites 11 and 26}

Figure 8 shows the chloride-depth profiles derived from groundwater samples at different locations within the agricultural fields of site 11 and site 26 (for location, see Fig. 4cd). For both sites, we measured a relatively constant chloride depth profile beneath the ditch, with a chloride concentration of $16 \mathrm{~g}^{-1}$ for site 11 and $12 \mathrm{~g} \mathrm{l}^{-1}$ for site 26 . In contrast to the locations in the field, there was no mixing beneath the ditch and upward flowing saline groundwater exfiltrates in the ditches without mixing. At most monitoring locations in both fields, the same salinities as beneath the ditches were found at 3 to $4 \mathrm{~m}$ depth, but upwards from here the salinity decreased, indicating the presence of the mixing zone. Although there were no significant differences in mixing zone characteristics for the different distances from the ditch at site 26 , the position in relation to the drains did have an impact on the mixing zone. The monitoring locations near drains showed a smaller mixing zone at a shallower depth when compared to the monitoring locations between drains (site 26, Fig. 8).

In agricultural site 11 we found a large spatial variation in the salinity profiles (Fig. 8). Within about $200 \mathrm{~m}$, the salinity at 2 to $4 \mathrm{~m}$ depth increased from fresh $(\mathrm{Cl}=0.03-$ $\left.0.05 \mathrm{~g}^{-1}\right)$ at the sandy creek ridge, mp 10, to almost seawater $\left(\mathrm{Cl}=14\right.$ to $\left.16 \mathrm{~g} \mathrm{l}^{-1}\right)$ in the lower-lying clay area, $\mathrm{mp} 1$ to $\mathrm{mp} 7$. Location $\mathrm{mp} 8$ showed an intermediate salinity profile between these two extremes (Fig. 8). This large spatial salinity gradient at site 11 was identified by all the measuring techniques we used (i.e. groundwater sampling, TEC-probe, ECPT, CVES, EM31, HEM). $D_{\text {mix }}$ and $B_{\text {mix }}$ derived from TEC-probe and ECPT measurements were plotted in a crosssection as well as the measured freshwater heads at $1.5 \mathrm{~m}$ and $4 \mathrm{~m}$ depth (Fig. 9). Although the spatial variation of rainwater lens thickness could be followed nicely with the CVESmeasurement, the exact lens characteristics $D_{\text {mix }}$ and $B_{\text {mix }}$ could not be derived. This is due to the fact that the penetration depth could not be derived exactly from the electrical measurements. As such, we plotted the $3 \Omega \mathrm{m}$ isoline of the real inverted soil resistivity in the cross-section to illustrate the strong gradient in groundwater salinity (Fig. 9).

As the confining layer is about 2.5 to $3 \mathrm{~m}$ thick at site 11 , the freshwater head at $4 \mathrm{~m}$ depth represents the regional hydraulic head of the upper aquifer. In the seepage area, where $D_{\text {mix }}$ was shallower than $2 \mathrm{~m}$, the freshwater head at $4 \mathrm{~m}$ depth was higher than the freshwater head at $1.5 \mathrm{~m}$ depth indicating upward vertical flow (Fig. 9). As freshwater head gradients are larger than the relative density difference that accounts for the buoyancy effect, the vertical flow direction (upward or downward) can be derived directly from the head measurements (Post et al., 2007). The average freshwater head difference was about $0.1 \mathrm{~m}$ ( $\mathrm{mp} 5$ to $\mathrm{mp} 8$ ) increasing towards the NW-ditch with a maximum freshwater head difference in the ditch of $0.65 \mathrm{~m}$. This large freshwater head difference at the ditch causes a strong upward seepage flux which hinders the infiltration of surface water which results in a constant salinity profile $\left(D_{\text {mix }}=B_{\text {mix }}\right)$. At the elevated sandy creek ridge, the freshwater head at $4 \mathrm{~m}$ depth was about $0.1 \mathrm{~m}$ lower than at $1.5 \mathrm{~m}$ depth, creating a downward flow and a much thicker rainwater lens with $D_{\text {mix }}$ at 4 to $7 \mathrm{~m}$ depth and $B_{\text {mix }}$ at 8 to $10 \mathrm{~m}$ depth. The strong upconing of saline groundwater was remarkable at the SE-ditch in the sandy creek ridge at only a few metres distance from the area where rainwater infiltrates to a large depth (Fig. 9). Due to the low surface water level maintained in the ditch of $-1.95 \mathrm{~m} \mathrm{~m} . \mathrm{s} .1$. (the same as for NW-ditch), the approximately $0.6 \mathrm{~m}$ higher freshwater head in the upper aquifer creates a strong upward flow of saline groundwater. The freshwater head and salinity measurements at site 11 prove that the vertical flow direction (seepage or infiltration) even with small freshwater head differences can cause large differences in rainwater lens thickness. 

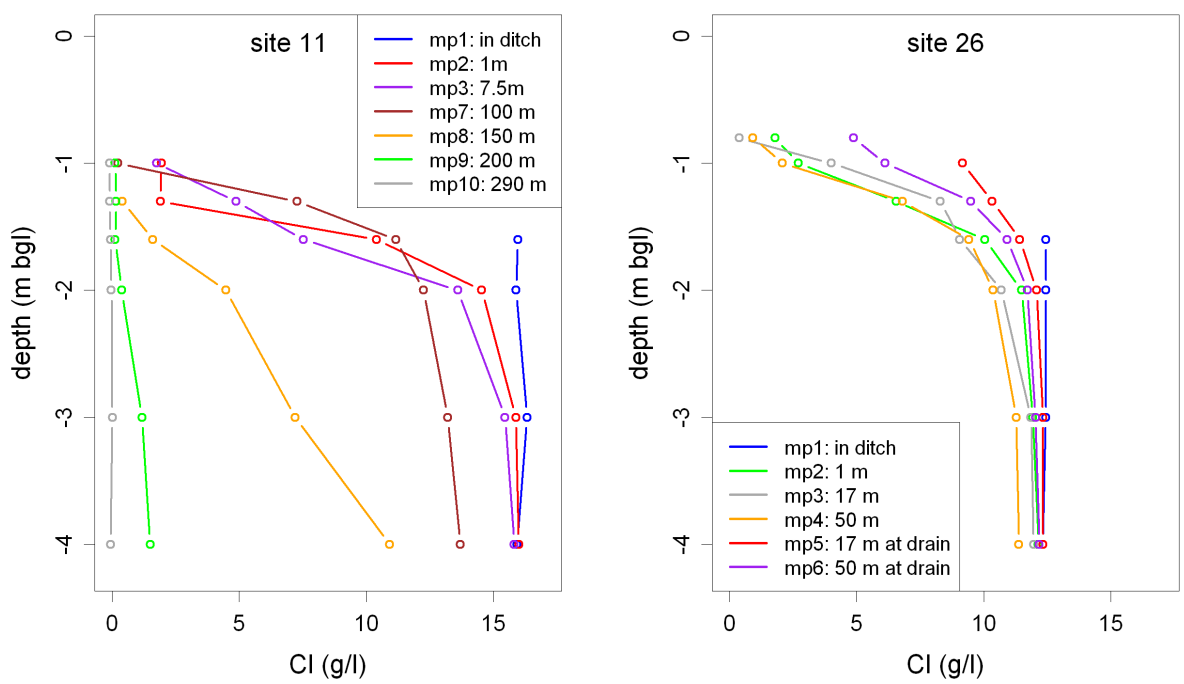

Fig. 8. Salinity profiles measured by groundwater sampling for sites 11 and 26 (on 21 January 2010).

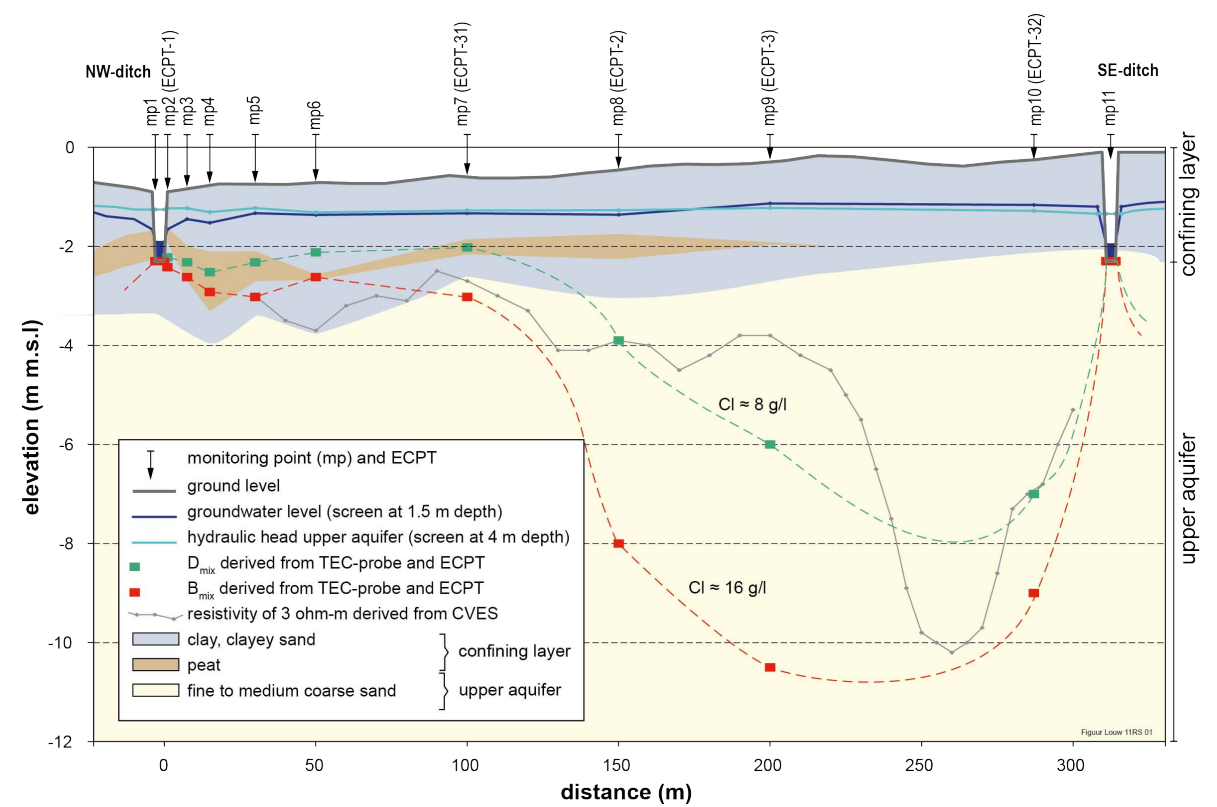

Fig. 9. Cross-section of site 11 with the measured hydraulic head at $1.5 \mathrm{~m}$ and $4 \mathrm{~m}$ depth (on 21 January 2010 ), $D_{\text {mix }}$ and $B_{\text {mix }}$ derived from TEC-probe and ECPT, and the real inverted soil resistivity isoline of $3 \Omega \mathrm{m}$ derived from CVES measurements. Note that the CVES-line was situated about $60 \mathrm{~m}$ from the 1-D measurements (Fig. 4c) and therefore shows a sharper gradient.

\subsubsection{Comparison of 3-D-model and monitoring results at site 11}

The techniques applied at agricultural site 11 are complementary to each other, varying from absolute chloride profiles (down to $4 \mathrm{~m}$ depth) and ECPT conductivity profiles (down to $25 \mathrm{~m}$ depth) at point scale to the surface (CVES, EM31) and airborne (HEM) measurements to follow the spatial variation of the rainwater lenses. This made the site suitable for evaluating the performance of the rainwater lens model in both an infiltration and a seepage situation. Figure 10 shows the comparisons between the field observations and the model results for the 3-D-numerical model. We found that the spatial variation of the modelled chloride concentration, averaged for the top $6 \mathrm{~m}$ (Fig. 10a) showed good agreement with the EM31-measurements (Fig. 10b): with low salinities on the sandy creek ridge and high salinities in the seepage area. The calculated bottom of the mixing zone $\left(B_{\text {mix }}\right)$ at the sandy creek ridge was about $8 \mathrm{~m}$ below ground level, which is in agreement with the ECPT and HEM results 


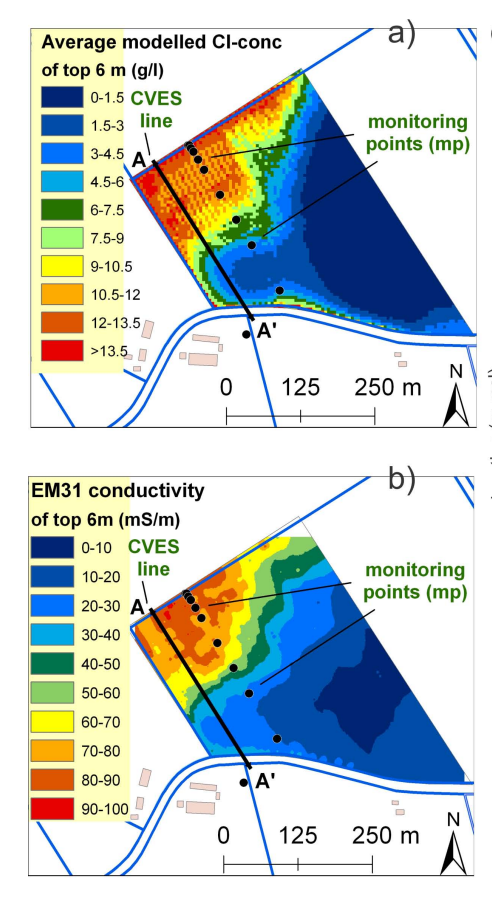

c) Cl-depth profiles

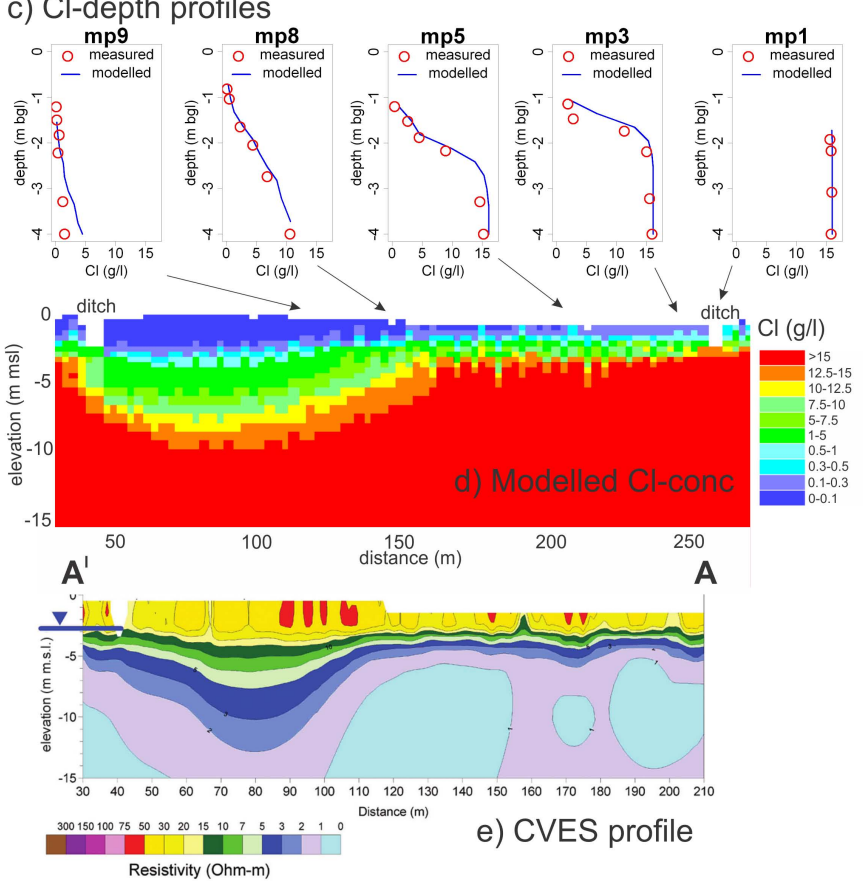

Fig. 10. Comparison of model results (3-D-model) with field measurements (EM13, Cl-depth profiles, CVES) for site 11.
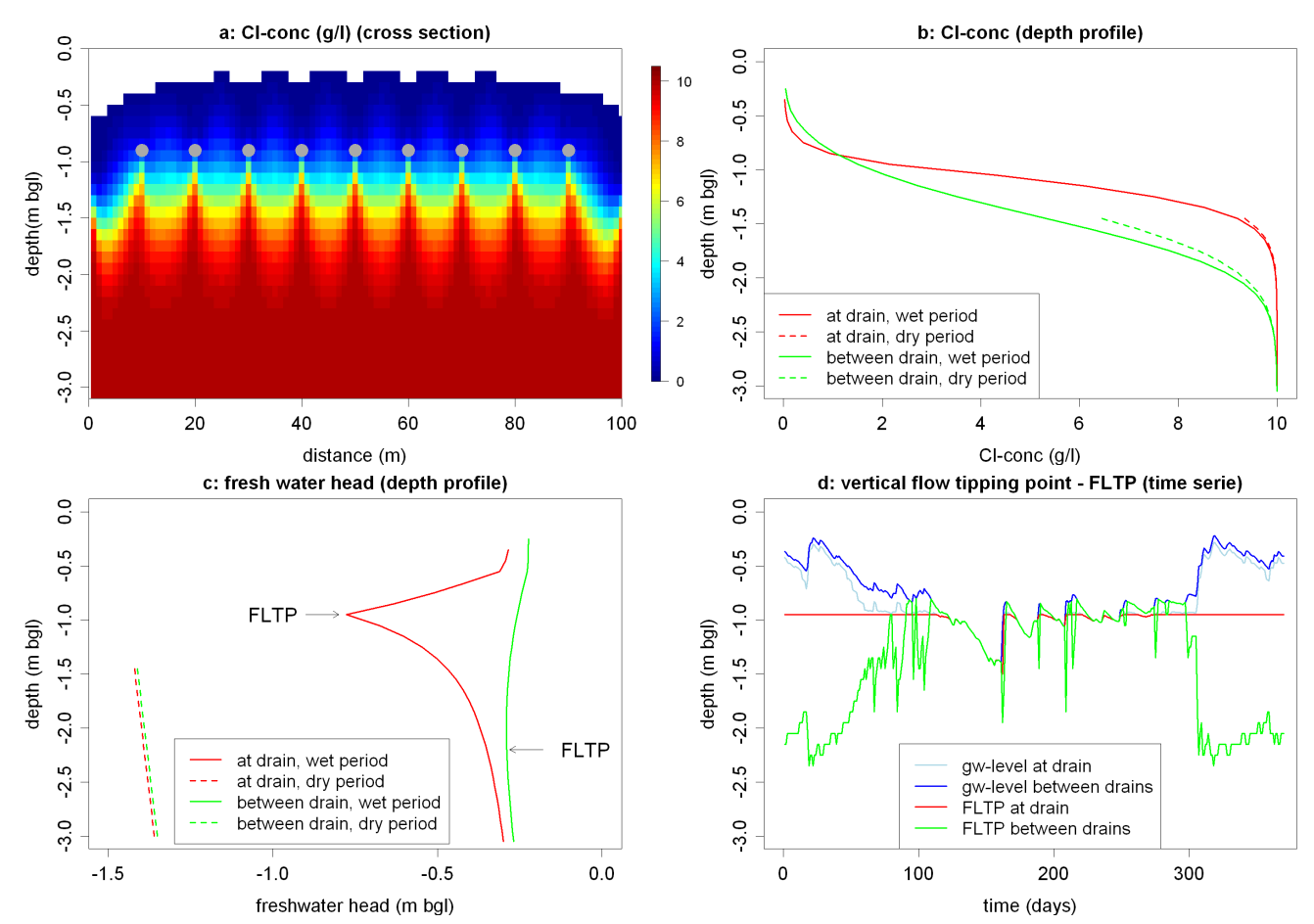

Fig. 11. Model results of the reference 2-D-model. (a) Cl-concentration in cross-section between two ditches (wet period). (b) Cl-conc. depth profile for a location at and between drains (wet and dry period). (c) Freshwater head depth profile for location at and between drains (wet and dry period). (d) Time series of vertical flow tipping point (FLTP) and groundwater level for a location at and between drains. 

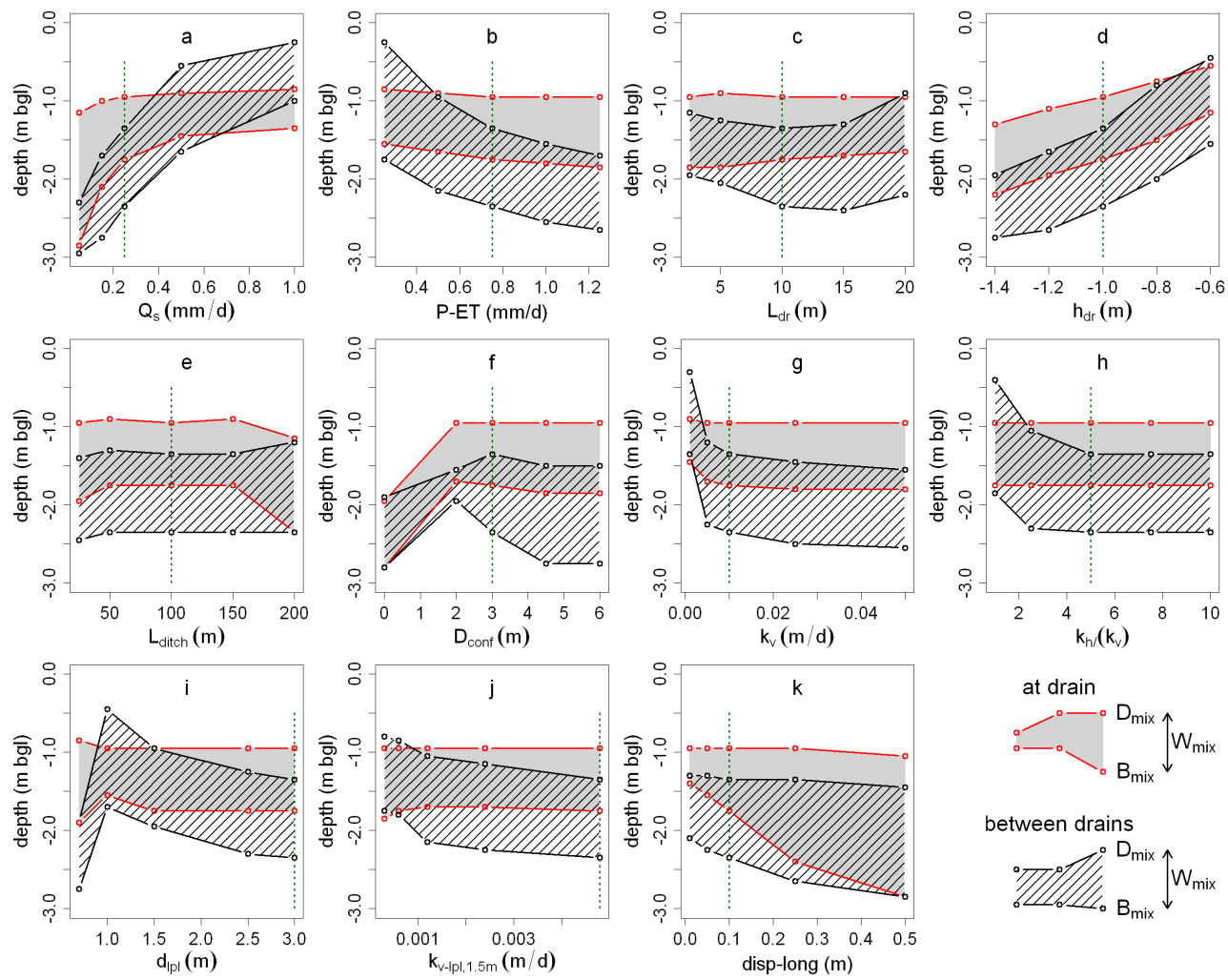

Fig. 12. Results of the sensitivity analysis for the 11 most sensitive parameters for lens characteristics $D_{\text {mix }}, B_{\text {mix }}$ and $W_{\text {mix }}$ (effect $>0.1 \mathrm{~m}$ ). The x-axis gives the parameter values of the reference model and the four sensitivity models; the y-axis gives the position of $D_{\text {mix }}$ and $B_{\text {mix }}$ for the different models, for a location at a drain and between two drains. The green dotted line indicates the position of the reference model.

(ECPT 32 in Figs. 7 and 9). The lateral variation of rainwater lens thickness measured by the 1-D techniques ( $D_{\text {mix }}$ and $B_{\text {mix }}$, see Fig. 9) and CVES (see Figs. 9 and 10e) is well reproduced by the numerical model (Fig. 10d). The measured chloride profiles, both absolute concentrations and the position and width of the mixing zone, showed good agreement with the modelled profiles (Fig. 10c). To summarize, the current fresh and saline groundwater system could be simulated well with the 3-D numerical model.

\subsubsection{Results of 2-D-model}

The findings of the 3-D-model (parameterization and schematization) were used to construct the conceptual 2-Dmodel for the seepage area. Figure 11 shows the results of the 2-D reference model. Upconing of saline groundwater at the drains was clearly visible, whereas the rainwater lens reached a greater depth between the drains (Fig. 11a and b). This corresponds with the measurements at site 26 (Fig. 8). The chloride profile and freshwater head were plotted for a location between two drains, and at a drain (Fig. 11b-c). This was done for the time step with the highest freshwater heads (wet period) and for one with the smallest freshwater heads (dry period). The heads between the drains were significantly higher than at the drains for the wet period. In the dry period, when heads dropped below drain level, the heads were equal.

The sensitivity of 19 model input parameters (Table 2) was tested for the lens characteristics; the centre depth $D_{\text {mix }}$, the bottom $B_{\text {mix }}$ and the half-width $W_{\text {mix }}$ of the mixing zone. Figure 12 shows the results for the model parameters with an effect larger than $0.1 \mathrm{~m}$ on one of these lens characteristics compared with the reference model. As $D_{\text {mix }}, B_{\text {mix }}$ and $W_{\text {mix }}$ did not fluctuate much through the whole period (annual amplitude about $0.1 \mathrm{~m}$ ), we presented average values in Fig. 12 . The effects on $D_{\text {mix }}$ and $B_{\text {mix }}$ were more evident between the drains than at the drains. The parameters seepage flux $Q_{\mathrm{s}}$ (Fig. 12a), precipitation surplus P-ET (Fig. 12b) and drainage depth $h_{\text {dr }}$ (Fig. 12d) had the largest effect on $D_{\text {mix }}$ and $B_{\text {mix }}$. Larger $Q_{\mathrm{s}}$ and smaller P-ET led to a mixing zone at shallower depth. $D_{\text {mix }}$ at the drains was always within $0.1 \mathrm{~m}$ of the applied drainage depth $h_{\mathrm{dr}}$. The longitudinal dispersivity $\alpha_{1}$ was obviously the principal factor for $W_{\text {mix }}$ (Fig. 12k). The other parameters not presented in Fig. 12 (including the chloride concentration of the seepage $\mathrm{Cl}_{\mathrm{s}}$, drainage resistance of the drains $\Omega_{\mathrm{dr}}$, drainage resistance of the ditch bottom $\Omega_{\mathrm{ditch}}$, and porosity $n$ ) did not significantly influence the lens (effects were smaller than $0.1 \mathrm{~m}$ ). The results of the sensitivity analysis will be further discussed in Sects. 4.4, 4.5 and 4.6. 


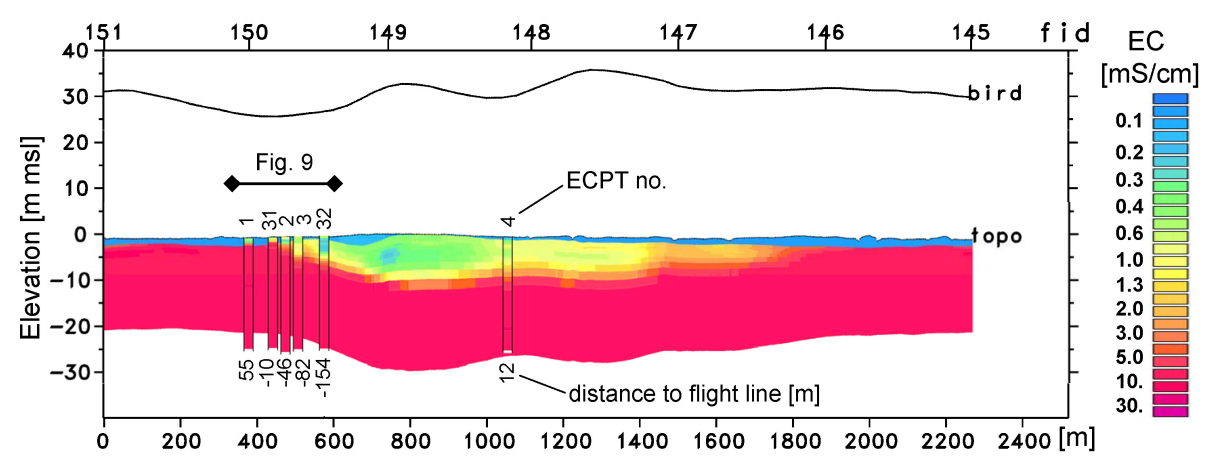

Fig. 13. Cross-section showing the electrical conductivity of smooth 15-layer HEM inversion models along a west-east flight line and nearby ECPT measurements (for location see Fig. 14).

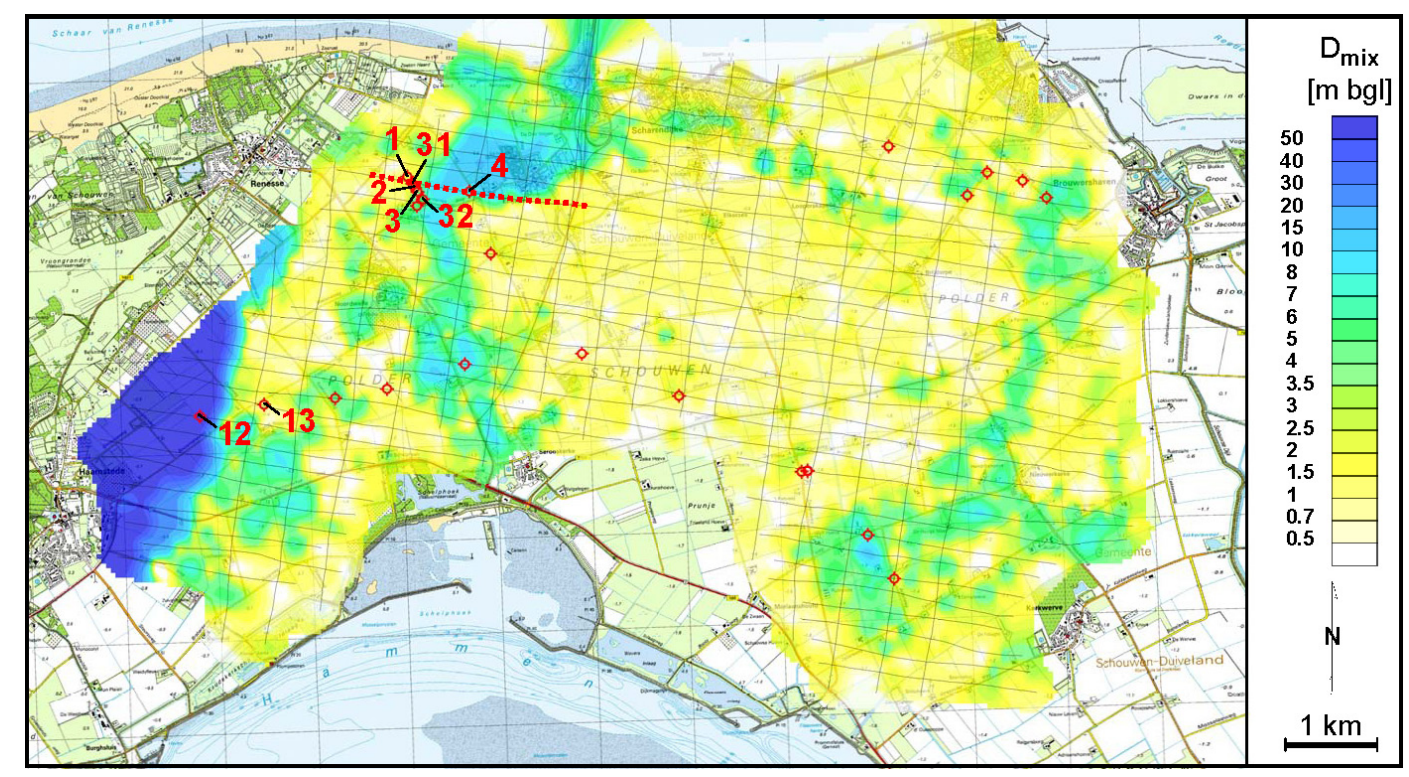

Fig. 14. Estimated depth $D_{\text {mix }}$ (average position of the mixing zone in m below ground level) derived from HEM inversion models. All flight lines (black lines) and the location of the ECPTs (red circles, those shown in Figs. 7 and 13 are numbered) are plotted on top of the depth map. The red dots indicate the position of the cross-section shown in Fig. 13.

\subsection{Spatial variation of rainwater lens thickness: HEM results}

The HEM data inverted to layered-earth resistivity-depth models reveal the spatial distribution of the electrical conductivity down to depths of about $20-30 \mathrm{~m}$ in the lowlands and of more than $60 \mathrm{~m}$ in the dune area. Conductivity contrast of fresh and saline groundwater dominated the inverted HEM models rather than differences in lithology. 2-D crosssections were produced for all survey lines. As an example, part of a west-east flight line is shown in Fig. 13 crossing the agricultural field of site 11 and the sandy creek ridge. The results of the smooth multi-layer HEM models agreed very well with nearby ECPT measurements, which are plotted as coloured columns in the cross-section. Only ECPTs having a horizontal distance of less than the maximum footprint size of the HEM measurements $(150 \mathrm{~m})$ were projected to the flight-line. Figure 7 shows a comparison of six ECPT soundings and corresponding HEM models at site 11 (ECPT 31, 2, $32,4)$ and close to the dune area (ECPT 12 and 13).

The analysis of the mixing zone derived from the detailed TEC-probe and ECPT data showed that the depth of the centre of the mixing zone, $D_{\text {mix }}$, is a consistent and easy to determine parameter to characterize the rainwater lens. We used $D_{\text {mix }}$ to indicate the thickness of the rainwater lens which also includes the unsaturated zone. To derive $D_{\text {mix }}$ from the HEM data, we determined the depth of the strongest vertical conductivity gradient within a resistivity range of $2-5 \Omega \mathrm{m}$. This was done for the 843001 1-D resistivity-depth inversion models and interpolated to a $50 \mathrm{~m}$ grid size map (Fig. 14) representing $D_{\text {mix }}$ for the entire airborne survey area. In a large part of the survey area $(>50 \%)$ 
the mapped rainwater lens was thinner than $2 \mathrm{~m}$. Thicker rain water lenses occurred in the eastern part of the survey area $\left(D_{\mathrm{mix}}=5-10 \mathrm{~m}\right.$ b.g.1. $)$, close to site 11 and the adjacent fossil sandy creek $\left(D_{\mathrm{mix}}=8-20 \mathrm{mb}\right.$ b.g.l. $)$ and, of course, in the dune area $\left(D_{\operatorname{mix}}>20 \mathrm{~m}\right.$ b.g.l. $)$.

The HEM-survey on the island of Schouwen-Duivenland made it possible to analyse the spatial variation of rainwater lenses by correlating $D_{\text {mix }}$ derived from the 84300 HEM-models, to geographically varying features. The thickness of the rainwater lens, $D_{\text {mix }}$, is clearly related to surface elevation (Fig. 15a) and to seepage and infiltration fluxes (Fig. 15b). Note that surface elevation and seepage/infiltration flux are strongly correlated; seepage occurs in low-lying polders below sea level and infiltration occurs in dunes, sandy creek ridges and polder areas above sea level (compare Fig. 2c with e). The HEM-results showed that rainwater lenses in low-lying seepage areas were, on average, $2 \mathrm{~m}$ thick (i.e. from ground level to $D_{\text {mix }}$ including unsaturated zone). The thinnest rainwater lenses were found in areas below $-2 \mathrm{~m}$ m.s.l. There was a sharp increase in thickness when vertical flow changed from seepage to infiltration (Fig. 15b). This shows that vertical flow (seepage or infiltration and fluxes) is the mechanism that controls the development of rainwater lenses.

\subsection{Vertical flow tipping point}

Both the freshwater head and salinity measurements at site 11 (Fig. 9) and the correlation of $D_{\text {mix }}$ with seepage/infiltration flux (Fig. 15) show that rainwater lens thickness is mainly the result of the vertical head gradient and vertical flow. To extend the understanding of the role of vertical flow on rainwater lens characteristics, we studied the vertical head and flux profiles of the 2-D-model results in more detail. Here we introduce the vertical flow tipping point (FLTP), which is the depth below ground level where the downward flow component meets the upward flow component. This point is best illustrated with a freshwater head depth profile at a drain, see Fig. 11c. Drainage of groundwater causes a dip of the hydraulic head at the drains, which results in groundwater flow towards the drain from both above and below. As variable density flow is driven by both head gradients and density differences, we determined FLTP from the calculated vertical fluxes directly rather than deriving it from the calculated freshwater head gradients. Figure 11d shows the daily FLTP for a period of $1 \mathrm{yr}$ for the reference model. At the drains, the FLTP was always at drainage level, except in the periods when groundwater levels dropped below the drains. Then the vertical flow component was upwards for the entire saturated profile and the FLTP equalled the groundwater level. The FLTP between the drains was much more variable with time than the FLTP at the drains (Fig. 10d). The maximum depth of FLTP between the drains was $2.35 \mathrm{~m}$, which occurred when the groundwater level was at its maximum and causing the largest downward head gra-
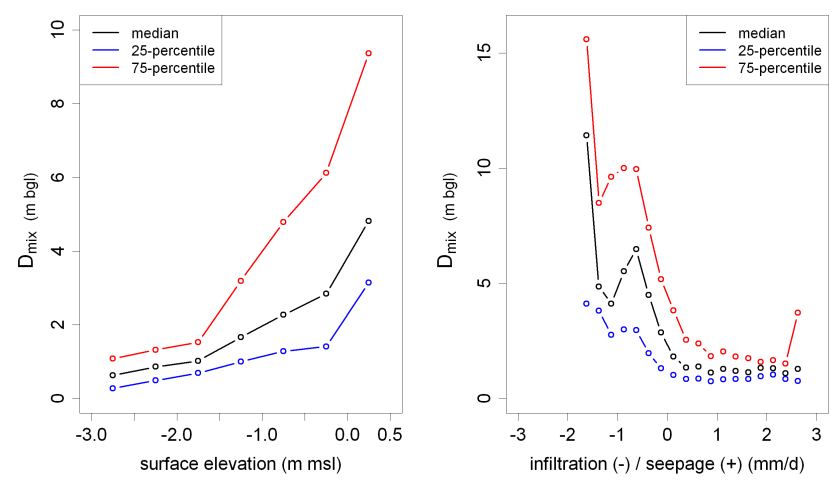

Fig. 15. Relation of $D_{\text {mix }}$ derived from 84300 HEM-measurements with (a) surface elevation ( $\mathrm{m}$ m.s.l.) and (b) infiltration and seepage flux $\left(\mathrm{mm} \mathrm{d}^{-1}\right)$. The 25-, 50- and 75-percentile of $D_{\text {mix }}$ was determined and plotted for different classes of surface elevation and flux (dots represent middle of class).

dient. When the groundwater level dropped, the FLTP moved to shallower depth and upward flow became more important. During the dry season, when groundwater levels dropped below the drains, there was only upward groundwater flow and the FLTP was equal to the groundwater level. The temporal variation of FLTP was driven by groundwater level fluctuations resulting from the daily variation of precipitation and evapotranspiration and intense drainage of groundwater.

The FLTP time series (one year of daily fluctuating FLTPs) were determined for all 76 sensitivity models, for which the parameters are listed in Table 2 as well as the correlation with the lens characteristics $D_{\text {mix }}, B_{\text {mix }}$ and $W_{\text {mix }}$. For nearly all sensitivity cases, the FLTP at the drains was situated at drainage level during periods when groundwater levels were above drainage level. The depth of the centre of the mixing zone, $D_{\text {mix }}$, at the drain was also situated at drainage level in $90 \%$ of the sensitivity cases. Although $D_{\text {mix }}$ was fixed at the drains, $D_{\text {mix }}$ between the drains was much more variable between the different sensitivity cases (see Fig. 12) and other parameters than drainage level $\left(h_{\mathrm{dr}}\right)$ played an important role. For every sensitivity model, the average depth of the FLTP between the drains was determined from the FLTPtime series and plotted against $D_{\text {mix }}$ (Fig. 16a). The scatter plot shows that $D_{\text {mix }}$ between the drains had a strong linear and positive correlation with the annual average position of the FLTP between the drains $\left(R^{2}=0.91\right)$. It is remarkable that the large variation of FLTP between the drains during the year resulted in a fairly steady depth of $\mathrm{D}_{\text {mix }}$ (maximum annual amplitude $=0.1 \mathrm{~m}$ ). This can be explained by the fact that vertical flow velocities were very small (maximum of $1.2 \mathrm{~mm} \mathrm{~d}^{-1}$ ) compared to the change in position of the FLTP (annual amplitude $=1.5 \mathrm{~m}$ ). Note that the upward or downward movement of a water particle is not exactly vertical because its flow path is the result of both the vertical and horizontal flow components. The calculated horizontal flow velocities were on average 1.7 times larger than the vertical flow velocities. 

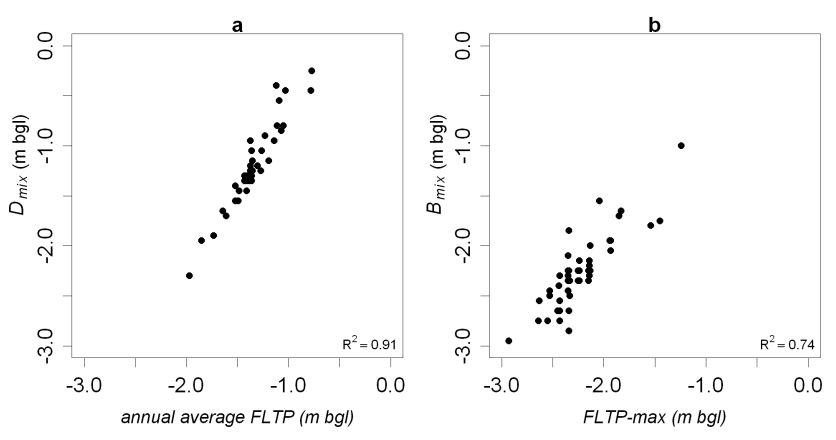

Fig. 16. Scatter diagrams of calculated vertical flow tipping points (FLTP) and lens characteristics $D_{\text {mix }}$ and $B_{\text {mix }}$ derived from the results of the different sensitivity models (see Table 2). The FLTP, $D_{\text {mix }}$, and $B_{\text {mix }}$ are derived for a location between two drains.

The bottom of the mixing zone $B_{\text {mix }}$ between the drains corresponded approximately with the maximum depth of FLTP which is the maximum depth where downward flow occurred during a year (Fig. 16b). Below FLTP-max the vertical flow direction is always upward and advective mixing is not possible. Mixing below FLTP-max between the drains can therefore only be the result of molecular diffusion. However, at the drains, $B_{\operatorname{mix}}$ was always below drainage depth and in most cases even 0.5 to $1.0 \mathrm{~m}$ deeper than FLTP-max at the drains. Additionally, $B_{\text {mix }}$ at the drains was correlated with $B_{\text {mix }}$ between the drains $\left(R^{2}=0.46\right)$, which indicates that mixing below the drains occurred by upward flow of groundwater that was infiltrated between the drains. The results show that the constantly alternating upward and downward flow at low velocities in the confining layer indicated by the varying position of the FLTP is the main mechanism of mixing between rainwater and saline seepage and determines the position and extent of the mixing zone.

\subsection{Controlling factors: geohydrology, drainage, seepage flux and recharge}

Our measurements show that the mixing of the upward flowing saline groundwater with infiltrating rainwater occurred in the confining top layer. This was caused by the permanently higher freshwater heads in the upper aquifer compared to the lower part of the confining top layer. FLTPmax was therefore always situated within the confining layer and consequently also $B_{\text {mix }}$. Given that lenses in seepage areas develop within the confining layer, the heterogeneity of the confining layer may have an additional effect on the lens characteristics. The sequence of confining sediments with different vertical hydraulic conductivities determines the freshwater head change with depth within the confining layer. When these freshwater head gradients are large enough, they influence the FLTPs and therefore $D_{\text {mix }}$ and $B_{\text {mix }}$. The sensitivity analysis showed that a $0.2 \mathrm{~m}$ thick low permeable layer $\left(k_{\mathrm{v}}=10^{-3} \mathrm{~m} \mathrm{~d}^{-1}\right)$ within the confining layer $\left(k_{\mathrm{v}}=10^{-2} \mathrm{~m} \mathrm{~d}^{-1}\right)$ had a significant impact when it was put in the upper $2 \mathrm{~m}$ of the confining layer (Fig. 12i, parameter $d_{\mathrm{lpl}}$ ). When the low permeable layer was situated above the drains, drainage of groundwater was much more difficult, resulting in higher groundwater levels, deeper FLTPs and thicker rainwater lenses between the drains. A low permeable layer situated below the drains hinders the further downward flow between the drains, resulting in shallower FLTPs and thinner rainwater lenses between the drains (Fig. 12i).

The large impact of drainage depth on $D_{\text {mix }}$ and $B_{\text {mix }}$ was shown by our field measurements (Fig. 8) and model calculations (Figs. 11 and $12 \mathrm{~d}, h_{\mathrm{dr}}$ ). At the drains, upconing of saline groundwater was observed (Fig. 8) and calculated (Fig. 11a) and $D_{\text {mix }}$ was fixed at drainage level. Besides the drainage depth, the magnitude of incoming fluxes, both from above (recharge) and below (seepage), had a large impact on lens characteristics (Fig. 12a-b, $Q_{\mathrm{s}}$ and P-ET). More recharge led to higher groundwater levels and consequently to deeper FLTPs and therefore to thicker rainwater lenses. Thinner lenses are calculated with larger upward-seepage fluxes, which cause the FLTPs to move upwards. The dominant role of recharge and upward-seepage makes the shallow rainwater lenses very vulnerable to climate change and sea level rise. The Royal Netherlands Meteorological Institute (KNMI) formulated four different climate scenarios which are equally likely to occur (van den Hurk et al., 2006). The $W^{+}$climate scenario is the driest $(2.5 \%$ reduction of precipitation and $7.5 \%$ increase of evapotranspiration) and has the largest expected sea level rise of $0.85 \mathrm{~m}$ by the year 2100 . A sea level rise would cause an increase of the hydraulic head in the aquifers, which would result in an increase of seepage flux. However, this effect of sea level rise decreases rapidly with the distance from the Dutch coast as concluded by Oude Essink et al. (2010). Both sea level rise and a reduction of the precipitation surplus may lead to thinner rainwater lenses. Since drainage depth is another important factor that determines rainwater lens thickness, adapting the tile drainage systems may effectively reduce the negative consequences of climate change and sea level rise. Thus, a better understanding of rainwater lenses could lead to practical measures for maintaining agriculture water storage systems.

\subsection{Head-driven versus density-driven flow}

The sensitivity analysis showed that the salinity of the upward-seeping groundwater does not have a significant influence on lens characteristics. We varied the salinity of the seepage water between freshwater and seawater (Table 2) and effects on $D_{\text {mix }}, B_{\text {mix }}$ and $W_{\text {mix }}$ were smaller than $0.1 \mathrm{~m}$. Therefore we suggest that density-driven flow is of minor importance and lens characteristics in the seepage areas are principally controlled by head gradients. Simmons (2005) stated that even small concentration differences may lead to density-driven flow gradients equal to typical field-scale hydraulic gradients. Whether density-driven or head-driven flow is the dominant process is dependent on a complex 
interplay between fluid and soil properties, and the competing demands of both free and forced convection and dispersion. Our proposition that head-driven flow dominates the rainwater lens development in areas with saline seepage is supported by our different observations. Firstly, in seepage areas the hydraulic head in the upper aquifer was permanently higher than heads in the confining layer. This prevented the water from infiltrating to depths below the bottom of the confining layer. Secondly, large head gradients typically developed in these shallow groundwater systems, strongly influenced by intensive drainage and daily changing recharge. The vertical freshwater head gradients are generally much larger than the relative density difference that accounts for the buoyancy effect and therefore dominates vertical flow. Besides the large head gradients, the temporal variation of the FLTP played an important role. For depths above $B_{\text {mix }}$, the vertical flow direction changed throughout the year. During downward flow, the density-driven flow strengthened the head-driven flow whereas during upward flow the density-driven flow opposed the head-driven flow. The net effect of density-driven flow was diminished by this constantly changing vertical flow direction.

In contrast to the quick response of the intensively drained groundwater systems, there are the much slower responding groundwater systems where BGH-lenses develop; these slower systems have large drainage distances and no upward flow of saline water due to elevation like the dunes. The precipitation surplus is not drained but fully used for the recharge of the groundwater system. Under a relatively constant recharge regime, a gradual downward head gradient causes the downward flow of rainwater to much greater depths. In homogeneous aquifers, the vertical downward flow is then only limited by the buoyancy force of the surrounding saline groundwater and its density determines lens thickness. These systems build up much larger lenses than the head-driven flow systems in the intensively drained seepage areas. This difference in the lens developing mechanisms explains the sudden increase in lens thickness shown in Fig. 15b when moving from a seepage situation to one of infiltration.

\section{Conclusions}

We determined the main characteristics and spatial variability of shallow rainwater lenses in areas with saline seepage and the mechanisms controlling them. Our findings are based on different types of field measurements and detailed numerical groundwater models applied in the south-western delta of the Netherlands. We observed a gradual mixing zone between infiltrating fresh rainwater and upward-flowing saline groundwater. Detailed measurements at point scale (groundwater sampling, TEC-probe, ECPT) were needed to determine the precise form of the mixing zone and to fully characterize the rainwater lenses. The smooth curved mixing zone was best characterized by the depth of its centre $D_{\text {mix }}$, and by the bottom of the mixing zone $B_{\mathrm{mix}}$, where the salinity was equal to that of the seepage water. We were able to extrapolate these lens characteristics obtained by our point measurements to agricultural field scale using surface geophysics (CVES, EM31), and even to a larger area $\left(56 \mathrm{~km}^{2}\right)$ at regional scale using helicopter-borne electromagnetic measurements (HEM). In the seepage areas, the centre of the mixing zone $D_{\text {mix }}$ occurred at very shallow depth, on average 1.5 to $2 \mathrm{~m}$ below ground level, and the bottom, $B_{\text {mix }}$, occurred no deeper than $5.5 \mathrm{~m}$, always within the confining layer. Below this mixing zone, the salinity stayed relatively constant until at least $25 \mathrm{~m}$ depth, with chloride concentrations of 10 to $16 \mathrm{~g} \mathrm{l}^{-1}$. Since the mixing zone occurs at shallow depth and most rainwater lenses lack fresh groundwater, its position and width is of great importance for a sufficient supply of freshwater for crop growth. Capillary rise of saline groundwater is very likely to occur in the present situation, possibly causing damage to crops.

Head-driven vertical flow dominates the rainwater lens formation in areas with saline seepage in two ways at different scales. A regionally driven upward groundwater flow from the upper aquifer into the confining layer prevents the rainwater from infiltrating to depths below the bottom of the confining layer. This explains the limited size of the lenses. Mixing between rainwater and saline seepage water therefore always occurs within the confining layer driven by large vertical head gradients at a local scale. These head gradients in the confining layer constantly change due to the interplay of upward seepage, variable recharge and drainage of groundwater resulting in alternating vertical flow directions. The constantly alternating upward and downward flow at low velocities in the confining layer is the main mechanism of mixing and determines the position and dimensions of the lens. Whether a water particle is flowing upward or downward is indicated by the position of the vertical flow tipping point (FLTP) which is the depth where the downward flow component meets the upward flow component. The annual average position of the FLTP determines the position of the centre of the mixing zone $D_{\text {mix }}$ and the maximum depth of the FLTP determines the bottom of mixing zone $B_{\text {mix }}$. Recharge, seepage flux, and drainage depth are the controlling factors. Unlike rainwater lenses in seepage areas, the vertical downward flow of rainwater in the infiltration areas is only limited by the buoyancy force of the surrounding saline groundwater. This leads to much thicker rainwater lenses, varying from 5 to $15 \mathrm{~m}$ thick lenses in the sandy creek ridges to $100 \mathrm{~m}$ thick lenses in the dunes.

This study provides information on rainwater lens characteristics and formation mechanism for rain-fed coastal lowlands below sea level with upward saline seepage into a confining top layer and intense drainage of shallow groundwater. In these deltaic areas, freshwater availability is often limited to shallow rainwater lenses which are vulnerable to climate change and sea level rise. Our findings may 
help to formulate effective measures such as adapting tile drainage systems to compensate the negative consequences of these future threats. As density differences did not influence lens formation in areas with saline seepage, our findings may also be applicable to fresh groundwater systems. Rainwater lenses in brook valleys and wet meadows with upward groundwater seepage may limit the development of groundwater-dependent ecosystems. The great advantage of studying rainwater lens formation in saline seepage areas arises from the large salinity contrast between rainwater and groundwater, which is easy to measure, even by non-invasive geophysical methods.

Acknowledgements. This research is part of CLIWAT, the Interreg IVb project (www.cliwat.eu), and of the Dutch Knowledge for Climate Programme "Fresh Water Availability". The work was carried out in collaboration with the province of Zeeland, the Scheldestromen Water Board and the Zuidelijke Land en Tuinbouw Organisation. We thank the following persons for helping collect the field data: Bart Goes, Mike van der Werf, Tommasso Letterio, Francesco Sergi, Sjors Stevens, Bas de Veen, Corné Prevo, Valentina Marconi, Esther Vermue, Vincent Post, Julia Claas, Bram de Vries, Andre Cinjé, Rien van den Hoek, and Jan van der Velde, as well as the helicopter team of the German Federal Institute for Geosciences and Natural Resources (BGR), and particularly Angelika Ullmann for so thoroughly processing the HEM data. We thank Jackie Senior, Marco Antonellini and the anonymous reviewers for their valuable comments on the paper.

Edited by: A. Vandenbohede

\section{References}

Antonellini, M. and Mollema, P. N.: Impact of groundwater salinity on vegetation species richness in the coastal pine forests and wetlands of Ravenna, Italy, Ecol. Eng., 36, 1201-1211, 2009.

Archie, G. E.: The electrical resistivity log as an aid in determining some reservoir characteristics, Petroleum Transactions of AIME, 146, 54-62, 1942.

Badon Ghijben, W.: Nota in verband met de voorgenomen putboring nabij Amsterdam, Tijdschr, Van Koninklijk Instituut Van Ingenieurs, 5, 8-22, 1888 (in Dutch).

Bakker, M.: The size of the freshwater zone below an elongated island with infiltration, Water Resour. Res., 36, 109-117, 2000.

BMNED: Geotechnical research for CLIWAT pilot area B (climate change and water), Report 0100685/071032292, rev. B, 2011 (in Dutch).

Boekelman, R. H.: Development of freshwater lenses, Proc. 16th Salt Water Intrusion Meeting, Miedzyzdroje, Wolin Island, Poland, 5-9, 2001.

Collins, W. H. and Easley, D. H.: Fresh-water lens formation in an unconfined barrier island aquifer, J. Am. Water Resour. As., 35, 1-22, 1999.

Custodio, E. and Bruggeman, G. A.: Groundwater Problems in Coastal Areas, Studies and Reports in Hydrology, UNESCO, International Hydrological Programme, Paris, 1987.

de Louw, P. G. B., Oude Essink, G. H. P., Stuyfzand, P. J., and van der Zee, S. E. A. T. M.: Upward groundwater flow in boils as the dominant mechanism of salinization in deep polders, The Netherlands, J. Hydrol., 394, 494-506, 2010.

de Louw, P. G. B., van der Velde, Y., and van der Zee, S. E. A. T. M.: Quantifying water and salt fluxes in a lowland polder catchment dominated by boil seepage: a probabilistic end-member mixing approach, Hydrol. Earth Syst. Sci., 15, 2101-2117, doi:10.5194/hess-15-2101-2011, 2011.

Eeman, S., Leijnse, A., Raats, P. A. C., and van der Zee, S. E. A. T. M.: Analysis of the thickness of a freshwater lens and of the transition zone between this lens and upwelling saline water, Adv. Water Resour., 34, 191-302, 2011.

Fetter, C. W.: Position of the saline water interface beneath oceanic islands, Water Resour. Res., 8, 1307-1314, 1972.

Flowers, T. J.: Improving crop salt tolerance, Journal of Experimental Botany, 55, 307-319, 2004.

Friedman, P. S.: Soil properties influencing apparent electrical conductivity: a review, Comput. Electron. Agr., 46, 45-70, 2005.

Geotomographie: SensInv2-D - Manual, available at: www. geotomographie.de, 2004.

Giambastiani, B. M. S., Antonellini, M., Oude Essink, G. H. P., and Stuurman, R. J.: Saltwater intrusion and water management in the unconfined coastal aquifer of Ravenna (Italy): a numerical model, J. Hydrol., 340, 91-104, 2007.

Goes, B. J. M., Oude Essink, G. H. P., Vernes, R. W., and Sergi, F.: Estimating the depth of fresh and brackish groundwater in a predominantly saline region using geophysical and hydrological methods, Zeeland, the Netherlands, Near Surf. Geophys., 7, 401412, doi:10.3997/1873-0604.2009048, 2009.

Herzberg, A.: Die Wasserversorgung einiger Nordseebäder, J. Gasbeleucht. Wasserversorgung, 44, 815-819, 1901 (in German).

Jolly, I. D., McEwan, K. L., and Holland, K. L.: A review of groundwater-surface water interactions in arid/semi-arid wetlands and the consequences of salinity for wetland ecology, Ecohydrology, 1, 43-58, 2008.

Katerji, N., van Hoorn, J. W., Hamdy, A., and Mastrorilli, M.: Salinity effect on crop development and yield, analysis of salt tolerance according to several classification methods, Agr. Water Manage., 62, 37-66, 2003.

Keary, P. and Brooks, M.: An Introduction to Geophysical Exploration, 2nd edition, Blackwell Science, 1991.

Langevin, C. D., Shoemaker, W. B., and Guo Weixing, W.: MODFLOW-2000, The US Geological survey Modular GroundWater Model-Documentation of the SEAWAT-2000 Version with the Variable-Density Flow Process (VDF) and the Integrated MT3DMS Transport Process (IMT): US Geological Survey Open-file report 03-426, 2003.

Lebbe, L.: Parameter identification in fresh-saltwater flow based on borehole resistivities and freshwater head data, Adv. Water Resour., 22, 791-806, doi:10.1016/S0309-1708(98)00054-2, 1999.

Maas, K.: Influence of climate change and sea level rise on a Ghyben Herzberg lens, J. Hydrol., 347, 223-228, 2007.

McNeill, J. D.: Electromagnetic Terrain Conductivity at Low Induction Numbers, Geonics Ltd. Technical Note TN-6, Geonics Ltd., Mississauga, Ontario, Canada, 1980.

Meinardi, C. R.: Fresh and brackish groundwater under coastal areas and islands, GeoJournal 7.5, 413-425, 1983.

Meisler, H., Leahy, P. P., and Knobel, L. L.: Effect of eustatic sealevel changes on saltwater-freshwater relations in the Northern Atlantic coastal plain, U.S. Geological Survey Water-Supply Pa- 
per, 2255, 1984.

Navoy, A. S.: Aquifer-estuary interaction and vulnerability of groundwater supplies to sea level rise-driven saltwater intrusion, Ph.D. thesis, Pennsylvania State University, USA, 1991.

Oude Essink, G. H. P.: Impact of sea level rise on groundwater flow regimes. A sensitivity analysis for the Netherlands, $\mathrm{Ph} . \mathrm{D}$. thesis, Delft University of Technology, Delft Studies in Integrated Water Management: no. 7, ISBN 90-407-1330-8, 428 pp., 1996.

Oude Essink, G. H. P.: Salt water intrusion in a three-dimensional groundwater system in the Netherlands: a numerical study, Transport in Porous Media, 43, 137-158, 2001a.

Oude Essink, G. H. P.: Saltwater intrusion in 3-D large-scale aquifers: a Dutch case, Phys. Chem. Earth, 26, 337-344, 2001 b.

Oude Essink, G. H. P., Baaren, E. S., and de Louw, P. G. B.: Effects of climate change on coastal groundwater systems: A modeling study in the Netherlands, Water Resour. Res., 46, W00F04, doi:10.1029/2009WR008719, 2010.

Post, V. E. A.: Groundwater Salinization Processes in the Coastal Area of The Netherlands due to Transgressions during the Holocene, Ph.D. thesis, Free University Amsterdam, 2004.

Post, V. E. A. and Abarca, E.: Saltwater and freshwater interactions in coastal aquifers, Hydrogeol. J., 18, 1-4, 2010.

Post, V. E. A., Kooi, H., and Simmons, C.: Using hydraulic head measurements in variable-density ground water flow analyses, Ground Water, 45, 664-671, 2007.

REGIS II: Hydrogeological model of The Netherlands. Report: Vernes, R. W., van Doorn, Th. H. M.: From Guide layer to Hydrogeological Unit, Explanation of the construction of the data set, TNO report NITG 05-038-B, 2005 (in Dutch).

Rozema, J. and Flowers, T.: Crops for a salinized world, Science, 322, 1578-1582, 2008.

Sakr, S. A.: Validity of a sharp-interface model in a confined coastal aquifer, Hydrogeol. J., 7, 155-160, 1999.

Schot, P. P., Dekker, S. C., and Poot, A.: The dynamic form of rainwater lenses in drained fens, J. Hydrol., 293, 74-84, 2004.

Siemon, B., Christiansen, A. V., and Auken, E.: A review of helicopter-borne electromagnetic methods for groundwater exploration, Near Surf. Geophys., 7, 629-646, 2009.

Siemon, B., Ullmann, A., Mitreiter, I., Ibs-von Seht, M., Voß, W., and Pielawa, J.: Airborne geophysical investigation of CLIWAT pilot areas, survey area Schouwen, The Netherlands, 2011.

Sikkema, P. C. and van Dam, J. C.: Analytical formulae for the shape of the interface in a semi-confined aquifer, J. Hydrol., 56, 201-220, 1982.

Simmons, C. T.: Variable density groundwater flow: From current challenges to future possibilities, Hydrogeol. J., 13, 116-119, 2005.

Stafleu, J., Maljers, D. M., Gunnink, J. L., Menkovic, A., and Busschers, F. S.: 3-D modelling of the shallow subsurface of Zeeland, the Netherlands, Netherlands J. Geosci., submitted, 2011.

Steppuhn, H., van Genuchten, M. T., and Grieve, C. M.: Root-zone salinity. I. Selecting a product-yield index and response function for crop tolerance, Crop Sci., 45, 209-220, 2005.

Stuyfzand, P. J.: Hydrochemistry and Hydrology of the Coastal Dune Area of the Western Netherlands, Ph.D. thesis, Free University Amsterdam, ISBN 90-74741-01-0, 366 pp., 1993.

Stuyfzand, P. J. and Stuurman, R. J.: Recognition and genesis of various brackish to hypersaline groundwaters in The Netherlands, in: Proc. 13th Salt Water Intrusion Meeting, edited by:
Barrocu, G., University of Cagliari, Sardinia, 125-136, 1994.

Technical Report, Interreg IVB Project: CLIWAT - Adaptive and sustainable water management and protection of society and nature in an extreme climate, BGR Archives-No. 0129932, Hanover, 2011.

Tiemeyer, B., Moussa, R., Lennartz, B., and Voltz, M.: MHYDASDRAIN: A spatially distributed model for small, artificially drained lowland catchments, Ecol. Model., 209, 2-20, 2007.

Underwood, M. R., Peterson, F. L., and Voss, C. I.: Groundwater lens dynamics of atoll islands, Water Resour. Res., 28, 2889-902, 1992.

van Baaren, E. S., Oude Essink, G. H. P., Janssen, G. M. C. M., de Louw, P. G. B., Heerdink, R., and Goes, B.: Freshening/salinization of phreatic groundwater in the province of Zeeland: Results of 3-D-density dependent groundwater model, Deltares Report, 2011 (in Dutch).

van Dam, J. C. and Sikkema, P. C.: Approximate solution of the problem of the shape of the interface in a semi-confined aquifer, J. Hydrol., 56, 221-237, 1982.

van de Plassche, O.: Sea-level change and water-level movements in the Netherlands during the Holocene, Mededelingen Rijks Geologische Dienst, 36, 1-93, 1982.

van de Ven, G. P. (Ed.): Man-Made Lowlands, History of Water Management and Land Reclamation in The Netherlands, Matrijs, Utrecht, 2003.

van den Hurk, B., Klein Tank, A., Lenderink, G., van Ulden, A., van Oldenborgh, G. J., Katsman, C., van den Brink, H., Keller, F., Bessembinder, J., Burgers, G., Komen, G., Hazeleger, W., and Drijfhout, S.: KNMI Climate Change Scenarios 2006 for the Netherlands, KNMI, De Bilt, Scientific Report WR 2006-01, 2006.

van der Meij, J. L. and Minnema, B.: Modelling of the effect of a sea-level rise and land subsidence on the evolution of the groundwater density in the subsoil of the northern part of the Netherlands, J. Hydrol., 226, 152-166, 1999.

van der Eertwegh, G. A. P. H., Nieber, J. L., de Louw, P. G. B., van Hardeveld, H. A., and Bakkum, R.: Impacts of drainage activities for clay soils on hydrology and solute loads to surface water, Irrig. Drain., 55, 235-245, 2006.

van der Veer, P.: Analytical solution for steady interface flow in a coastal aquifer involving a phreatic surface with precipitation, J. Hydrol., 34, 1-11, 1977.

van der Velde, Y., de Rooij, G. H., and Torfs, P. J. J. F.: Catchment-scale non-linear groundwater-surface water interactions in densely drained lowland catchments, Hydrol. Earth Syst. Sci., 13, 1867-1885, doi:10.5194/hess-13-1867-2009, 2009.

van Meir, N.: Density-dependent Groundwater Flow: Design of a Parameter Identification Test and 3-D-simulation of Sea-level Rise, PhD thesis Thesis, Ghent University, Ghent, Belgium, 319 pp., 2001.

van Rees Veilinga, E., Toussaint, C. G., and Wit, K. E.: Water Quality and hydrology in a coastal region of The Netherlands, J. Hydrol., 50, 105-0127, 1981.

van Wirdum, G.: Vegetation and Hydrology of Floating Rich Fens, Ph.D. thesis, University of Amsterdam, 1991.

Vandenbohede, A., Luyten, K., and Lebbe, L.: Impacts of global change on heterogeneous coastal aquifers: case study in Belgium, J. Coastal. Res., 24, 160-170, 2008.

Vandenbohede, A. and Lebbe, L.: Effects of tides on a sloping 
shore: Groundwater dynamics and propagation of the tidal wave, Hydrogeol. J., 15, 645-658, doi:10.1007/s10040-006-0128-y, 2007.

Vos, P. and Zeiler, F.: Holocene transgressions of southwestern Netherlands, interaction between natural and antrophogenic processes, Grondboor \& Hamer, 3-4, 2008 (in Dutch).
Voss, C. I. and Provost, A. M.: SUTRA, a model for saturatedunsaturated variable density groundwater flow with solute or energy transport, manual, US Geological Survey, Reston, Virginia, USA, 2008.

Weert, F., van der Gun, J., Reckman, J.: Global Overview of Saline Groundwater occurrence and Genesis, Report no. GP 2009-1, 2009. 